Article

\title{
Sustainable Open Pit Mining and Technical Systems: Concept, Principles, and Indicators
}

\author{
Aleksandr Rakhmangulov*(D), Konstantin Burmistrov and Nikita Osintsev \\ Mining Engineering and Transport Institute, Nosov Magnitogorsk State Technical University, \\ 455000 Magnitogorsk, Russia; k.burmistrov@magtu.ru (K.B.); osintsev@magtu.ru (N.O.) \\ * Correspondence: ran@magtu.ru; Tel.: +7-(902)-89-96-900
}

Citation: Rakhmangulov, A.; Burmistrov, K.; Osintsev, N. Sustainable Open Pit Mining and Technical Systems: Concept, Principles, and Indicators. Sustainability 2021, 13, 1101. https://doi.org/10.3390/su13031101

Academic Editor: Alessandro Cavallo Received: 31 December 2020

Accepted: 19 January 2021

Published: 21 January 2021

Publisher's Note: MDPI stays neutral with regard to jurisdictional claims in published maps and institutional affiliations.

Copyright: (c) 2021 by the authors. Licensee MDPI, Basel, Switzerland. This article is an open access article distributed under the terms and conditions of the Creative Commons Attribution (CC BY) license (https:/ / creativecommons.org/licenses/by/ $4.0 /)$.

\begin{abstract}
Sustainability of the open pit mining and technical system (MTS) is one of its key goals in the changing conditions of the external and internal environment. All MTS's subsystems must function in concert to achieve this goal. The structure of the MTS is formed by many subsystems and elements, which are evaluated by a significant number of indicators. A comprehensive assessment of the MTS for all possible indicators is a complex and time-consuming task. However, each subsystem and element of the MTS has a different effect on the sustainability of this system. The MTS's parameters change significantly during transition periods, for example, at a new stage of open-pit mining or when switching to an open-underground method of developing mineral deposits. The MTS's sustainability declines during the transition periods. Changes in the parameters of technological processes during these periods can have a negative impact on the state of the economic and social subsystems of mining enterprises, as well as on the environment. Ensuring the sustainability of an MTS during transition periods requires the development of new approaches and principles for managing the work of mining enterprises, based on the alignment of economic goals, with goals in the field of ecology and social development. The study substantiates the key role of one of the MTS subsystems-the opening-up of an opencast system (OOS). It is shown that this system has a decisive influence on sustainable functioning and development. The systematization of the principles of sustainable functioning and development of mining enterprises and its systems has been carried out. Four groups of principles are distinguished: system-wide principles of management, principles of development of mining enterprises, principles of MTS development, and principles of the MTS's subsystem development. The proposed system of principles is based on the idea of a sequential transformation of the subsystems at all stages of design and operation. A feature of the proposal system of principles is the consideration of economic, social, and environmental aspects to ensure the specified parameters for the sustainable functioning and development of mining enterprises. The results of the analysis of the factors of the external and internal environment of the MTS are presented. The parameters and indicators for assessing the sustainability of OOS and MTSs were selected and substantiated. The justified parameters and indicators were ranked using the fuzzy Analytic Hierarchy Process (AHP). The results of the assessment showed a high convergence of expert opinions on a group of economic parameters, which were rather high in technical and technological parameters. However, there is a divergence of expert opinions on social and environmental parameters. As a result of the study, it was concluded that the current management decisions are aimed at ensuring the economic and technological sustainability of MTS functioning, while achieving the goals of sustainable development of this system is not ensured. The methodology developed and presented in the study can be used to assess the sustainability of the functioning and development of MTSs.
\end{abstract}

Keywords: mining and technical system; mining enterprise; opening-up of an opencast system; sustainable functioning; sustainable development; concept; principles; indicators; fuzzy AHP 


\section{Introduction}

The development of reserves of steeply dipping ore deposits by the open method is currently being carried out according to projects involving the final depths of open pits up to $800 \mathrm{~m}$ and more [1,2]. The economic indicators of a mining and technical system (MTS) deteriorate with the increase in the depth of the open pit. The structure of an MTS is formed by many subsystems. However, the greatest costs are observed in the subsystems associated with the operation of open pit transport. For example, the costs of transporting rock mass reach $60-70 \%$ of the total costs [3,4] and the costs of creating an opening scheme and equipping it with trucks reach $30-50 \%$ of the total costs of opening-up [5].

Ensuring the sustainability of MTS functioning is a priority task for a mining enterprises (MEs) in the context of an unstable external environment and deteriorating mining conditions for the development of mineral deposits. Technical and technological transformations in the subsystems of the MTS do not only affect the economic performance of the mining enterprise. They also significantly affect the state of the environment (increase in emissions of harmful substances, waste generation) and social changes (deterioration of working conditions for personnel, decrease in labor productivity, growth of social tension). Ensuring the sustainability of MTS functioning requires the development of new approaches to its management, based on a comprehensive assessment of the MTS and its subsystems. Such an assessment of the MTS is currently difficult for the following reasons: the disunity of the existing principles and goals of the functioning and development of different MTS systems, the absence of a system of interrelated indicators, and the presence of many parameters and contradictory indicators.

The study [6] proved that sustainable development for mining companies is a critical requirement for their current operations. Therefore, the motivation of the authors of this study is due to the need to improve the quality of the assessment of MTS sustainability. For this, the study systematizes the principles, parameters, and indicators of the MTS and its subsystems. The ranking of indicators was made to improve the quality of the assessment of sustainability. Such an assessment is the basis for making strategic decisions that ensure the alignment of the economic goals of MTS, with goals in the fields of ecology and social development.

The remainder of this paper is organized as follows. After the introduction, Section 2 presents a literature review containing three subsections. They consistently analyze the studies of the structure, functions, and factors of sustainable development of the MTS, then present studies of the MTS's principles of sustainable development, and finally provide an overview of publications in the field of calculating and applying various parameters and indicators of MTS functioning. Section 3 presents the author's concept of sustainable operation and development of the MTS. This concept includes a system of principles for sustainable development of the MTS during transition periods, as well as a set of parameters and indicators for assessing its sustainability. Section 4 contains a description of the fuzzy Analytic Hierarchy Process (AHP) and the results of its application to assess the development sustainability of one of the key subsystems of the MTS-the opening-up of an opencast system. In the conclusion, the main results of the study are presented, and the directions of its development are discussed.

An explanation of all abbreviations used in this article is given in Appendix A, Table A1.

\section{Literature Review}

\subsection{Structure, Functions, and Factors of Sustainable Development of the Open Pit Mining and Technical System}

The mining and technical system is a combination of mining structures, open and underground technical and technological subsystems, and physicochemical and special mining methods in interaction with the enclosing subsoil areas [7].

The presence of many approaches to the consideration of the structure of an MTS is the reason that different authors distinguish different systems and subsystems of MTSs. This is mainly due to the objectives of the study and the method used for the development 
of mineral deposits. An MTS is also considered as an element of more complex systems, such as a geosystem, a mining operation, or a mining and metallurgical holding [8].

The main elements of an open pit MTS are minerals, overburden, mine workings, mining structures, mining, and transport machines [7]. The main functions of an MTS are the production of a given quality and quantity at a given time and meeting the economic needs of stakeholders.

The effectiveness of the functioning of an MTS is influenced by many factors of the internal and external environment. Various factors have a strong influence on the sustainability of the MTS, including geological factors $[9,10]$, the level of infrastructure development in the region [11], technical factors [10,12-16], technological factors [17,18], environmental requirements [19-22], employees [21,22], and conditions of the socioeconomic environment [23].

The study of the features of MTS functioning carried out by the authors [8] established the following:

- The presence of a significant impact of the external environment on the MTS and its subsystems, characterized by many economic, environmental, social, organizational, and technological factors.

- Lack of systematic implementation of the principles of the concept of sustainable development in the MTS and its subsystems.

- The importance of the opening-up of an opencast system as the key to sustainable development and functioning of the MTS.

The choice of the MTS's development options largely depends on the layout of the opening-up of an opencast system (OOS). The key characteristics of the OOS are as follows: It requires from 20 to $70 \%$ of the mine's equipment (depending on the type of transport used), up to $50 \%$ of the mine's workers are involved, it generates up to $60 \%$ of the mine's pollutant emissions (excluding one-time emissions from blasting operations) and up to $50 \%$ of its waste (overburden from placement of opening workings and waste from operation). Moreover, up to $70 \%$ of the mine's operating costs for the development of the field are spent and up to $60 \%$ of its capital costs are concentrated on the OOS.

\subsection{The Principles of Sustainable Functioning and Development of the Open Pit Mining and Technical System}

A systematic literature review revealed the absence of clearly formulated principles of sustainable development for the mining industry, the implementation of which would allow achievement of the sustainable development goals formulated in [24]. The principles currently applied are focused on systems of various levels-from global principles at the mining enterprise level to specific principles for individual subsystems. Various principles are implemented both at the design stage and at the stage of development of a mineral deposit. It is proposed that the principles of design and development of systems in the mining industry, identified as a result of a systematic literature review, are divided into the following groups:

- General system principles, which are typical for systems of all levels-from mining and metallurgical holding to subsystems of the MTS [25];

- Principles implemented at the stage of ME design: pit design principles [26,27] and principle for setting contours for open-pit mining [28];

- Principles implemented in the development of mineral deposits in general: principles of development [29], principles of modern mining [30], principles of sustainable development of geotechnologies [7], methodological principles of work planning [31,32], and principles of environmental risk control [33];

- Principles of development of the MTS, implemented in the design and development of mineral deposits: the principle of reuse of open pit space and technogenic raw materials [34,35], the principles of system flow [36], the principles of geometallurgy [37], the principles of economic, environmental, social, and cultural sustainability [25,38-43], 
the principles of activity in the mining industry [22], and the principles of a methodological approach to solving the problems of subsoil development [44];

- Principles of development of an open pit or mine as an independent unit-the principles of a full cycle of development of a mineral deposit [7];

- Principle of concurrent mining and reclamation technology [45] and principles of organization of the MTS [11];

- $\quad$ Principles of MTS design [27], principles of ensuring sustainability of individual MTS elements [34,46-48], control principle [49,50], and optimization principle of combined open pit and underground mining [35].

Particular principles aimed at the development of individual MTS subsystems, including the OOS include principles of cyclic-flow technology in the development of deep open pits [51], the principle of formation of the opening scheme [52], the principles of formation of freight flows [53], based principles of high angle conveyors [54], principles of transport operation [55,56], principles of determining the moment of transition to a new mode of transport in the development of deep open pits [57], principles of the formation of transport systems of deep open pits [58], principles of modeling excavator-truck-conveyor complexes [59], and principles for mine closure planning [60].

Thus, it becomes clear that, at present, there is no universal system of principles for the sustainable development of an MTS and its subsystems. Most of the known principles are focused on high-level systems. Forty-nine percent of the principles identified relate to the level of a mining enterprise and above, $38 \%$ are applicable to MTSs, and only $13 \%$ are focused on MTS subsystems [8].

Moreover, a systematic review of the literature leads to the following conclusions. First, a systematic approach to implementing the principles of sustainable development in the mining industry is not being implemented. Secondly, the existing principles of design and development of MTSs and ME are focused primarily on the management of a mining enterprise and poorly consider the design and function of the MTS and its subsystems. This approach does not contribute to the sustainable development of MTSs and ME in general.

\subsection{Indicators and Methods for Assessing the Functioning of the Open Pit Mining and Technical System and Its Subsystems}

This section presents the results of a systematic literature review of studies in the field of the application of various parameters and indicators of the MTS and the OOS (Table 1). Parameters and indicators are systematized according to their compliance with the factors of the sustainable development of MTS and the OOS. Six large groups of factors were identified, considering the characteristics of the developed mineral deposit; the equipment used; and the technological, environmental, social, and economic characteristics of ME. This grouping and allocation of factors is because geological, technical, technological, and economic factors ensure the sustainability of the MTS operation. Social and environmental factors reflect the relationship between the peculiarities of the functioning of the OOS as part of the MTS and the concept of sustainable development. The results of the research review showed the absence of a universal set of parameters and indicators for assessing the MTS and the OOS, and, as a result, there is no unified approach to assessing an MTS and its subsystems.

Table 1. A review of research of existing parameters and indicators for evaluating the mining and technical system and the opening-up of an opencast system.

\begin{tabular}{cccc}
\hline No. & Factors/Elements & Parameters/Indicators & References \\
\hline & & Geological (Qualitative) $[9,54,61,62]$ & \\
& Mineral characteristic & Mineral quality and quantity & {$[9,61,62]$} \\
1. & & Quality of mined minerals & {$[9,61]$} \\
& Deposit characterization & Deposit geology & {$[9,10,54]$} \\
& & Weather condition & {$[13]$} \\
& & Stripping ratio & {$[10,54,63]$} \\
\hline
\end{tabular}


Table 1. Cont.

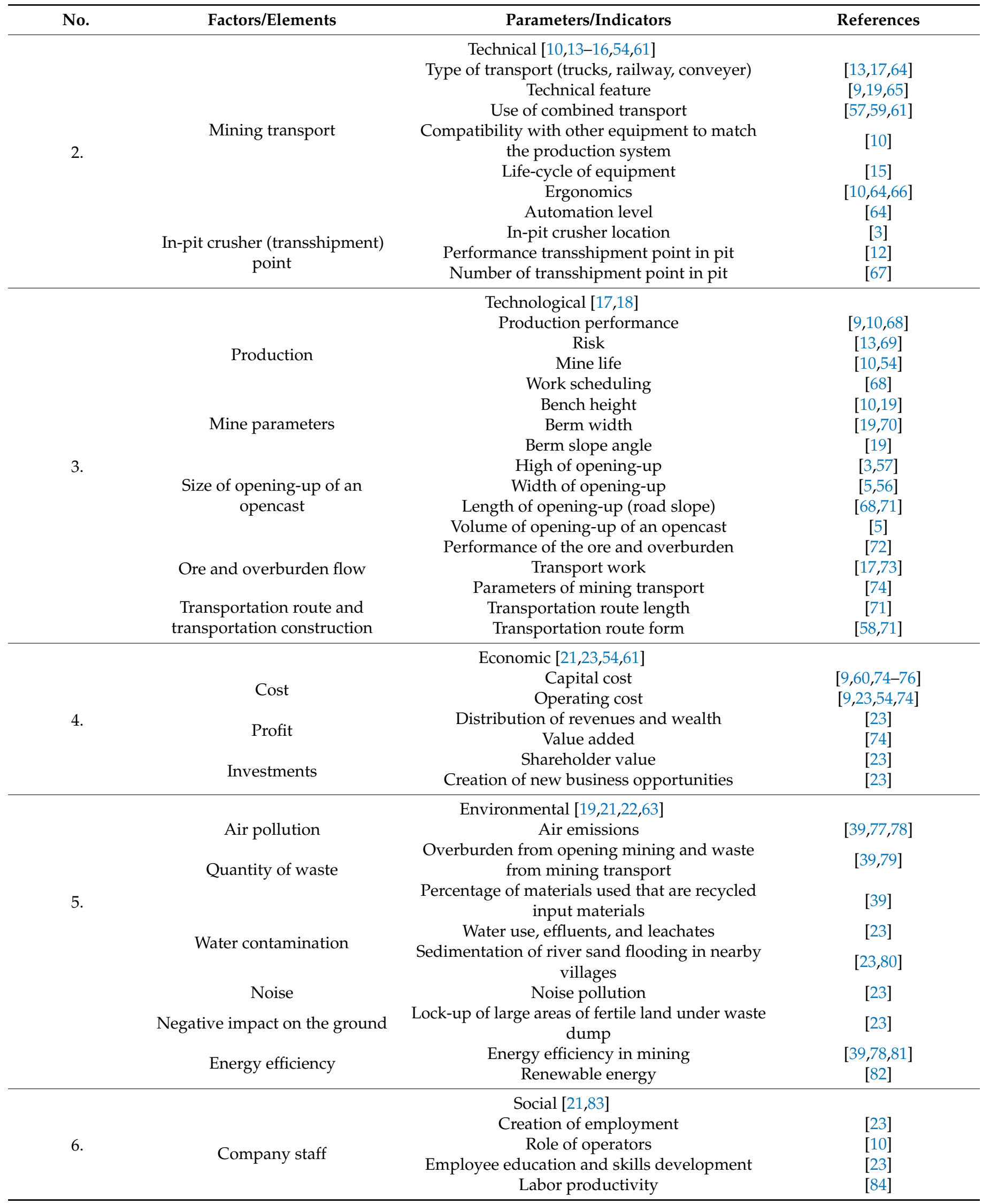


A systematic analysis of research and practice in the application of parameters and indicators for evaluating the MTS and the OOS led to the following conclusions.

- There is no system of indicators for a comprehensive assessment of the functioning and development of the MTS and the OOS from the standpoint of the concept of sustainable development.

- Assessment criteria are focused on economic, technical, and technological factors and poorly consider the environmental and social aspects of the functioning of the MTS and the OOS.

- Different ways of grouping factors of the external and internal environment of the MTS are used in different studies. The number of factor groups varies from three to six. Moreover, different researchers assign the same factors to different groups.

- The number of parameters and indicators used for evaluating the MTS and the OOS can vary from 6 to 69 . Furthermore, the assessment can both be carried out based on precise quantitative indicators, using approximate qualitative estimates.

- Geological, technical, technological, and economic factors are considered as factors of sustainability of MTS functioning, and economic, environmental, and social factors are considered as factors of sustainable development. Simultaneously, economic factors are considered as decisive for the sustainability of the functioning and development of the MTS and the OOS.

- Most of the parameters and indicators are focused on the assessment of large and complex systems such as ME or MTSs and cannot be used to assess the MTS subsystems, including OOS.

- At present, a methodological basis for assessing the functioning and sustainable development of the OOS as part of the MTS has not been formed.

The presence of many parameters and indicators for assessing an MTS and its subsystems makes it expedient to analyze the possibility of using multi-criteria methods for making management decisions relating to a comprehensive assessment of the sustainable functioning and development of the MTS and the OOS.

Currently, decision-making in the field of mining and the processing of minerals is complicated by several problems, the solutions to which require interdisciplinary knowledge from the decision maker, including geological, technical, technological, economic, environmental, and social aspects, as well as political peculiarities and regulatory legal acts. Making decisions on managing an MTS and OOS requires consideration of the following factors, in addition to those listed in Table 1.

- The objectives of the various stakeholders.

- Risks associated with geological data, mining methods, new technologies, land allocation, resource allocation, commodity prices, and market conditions, etc.

Multi-Criteria Decision Making (MCDM) approaches are widely used to solve such complex multi-factorial and multi-criteria problems. MCDM is a model that describes the decision making process, with many conflicting criteria and a set of alternatives. The use of MCDM facilitates quantitative and qualitative analysis under both known conditions and uncertainty [85].

MCDMs are widely recognized in the mining industry. MCDMs are used in both mining and mineral processing. The review [85] shows that the most widespread method is the Analytic Hierarchy Process (AHP), which is used alone or with other methods. The AHP method is effectively used for the selection of mining transport equipment $[9,86]$, for the selection of a site for the development of mineral deposits [16,62], the choice of technology $[9,64]$, and for the assessment of environmental factors of mining enterprises $[23,66]$. The main advantages of the method are $[10,66]$ : the ability to choose the best alternatives for each criterion and the ability to use quantitative and qualitative criteria, as well as alternatives on the same scale of preferences, simplicity of computational processes, and ease of verifying the consistency of judgments. In addition, AHP is supported by user-friendly software platforms such as Expert Choice and Super Decision. The use of 
fuzzy AHP, in contrast to the classical AHP proposed by Thomas Saaty [87], allows not only the avoidance of an imbalance in the scale of judgments, uncertainty, and subjectivity of expert judgments, but also to increase the accuracy of ranking [19].

Thus, the possibility of using fuzzy AHP to rank the parameters and indicators of the functioning and development of the MTS and the OOS is justified by the following considerations: a variety of factors of the external and internal environment of ME, the lack of an integrated approach to assessing all MTS subsystems, and insufficient consideration of the requirements of the concept of sustainable development in the management of MTS.

\section{The Concept of the Mining and Technical System Sustainable Functioning and Development \\ 3.1. Preliminary Considerations}

Assessment of the functioning of the MTS, as well as the feasibility of its development, is a complex multivariate task that requires an analysis of many indicators of all MTS subsystems. Various researchers distinguish from three to seven such subsystems in the structure of the MTS. Each subsystem has a different impact on MTS functioning and the development of sustainability. The authors consider the MTS as a set of technical, technological, organizational, economic, social, and ecological subsystems, as well as the OOS, ensuring the sustainable operation and development of the MTS at all stages of the development of a mineral deposit (Figure 1). MTS subsystems are interconnected by solving the main problem of efficiently transforming input material, information, and financial flows into marketable products of the required quantity and quality. In addition, the MTS generates man-made objects, emissions into the environment, various types of financial contributions, etc. The main system in the structure of the MTS is the OOS because it combines technical, technological, and organizational subsystems.
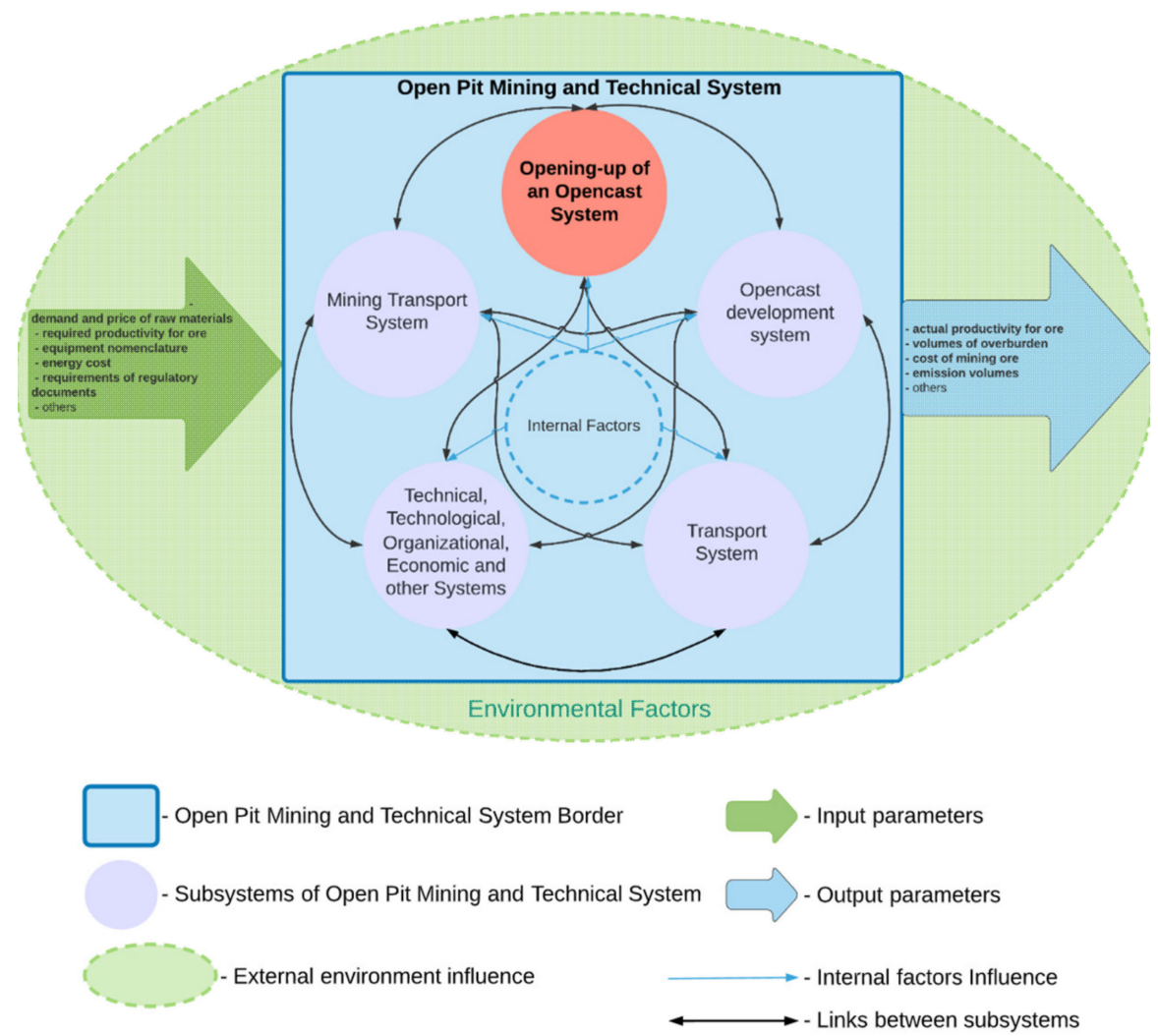

Figure 1. Scheme of the mining and technical system and its subsystems structure.

The opening-up of an opencast system (OOS) is defined by the authors as a complex technical and technological subsystem of the MTS, designed for the formation and transportation of freight flows of minerals, overburden, equipment, and materials, consisting of opening 
workings, mining transport, and devices, as well as in-pit crasher (transshipment) points of rock mass. The MTS is characterized by the number and purpose of its elements, the parameters of connections between them, and the duration of the functioning of the OOS elements in an unchanged form. The sustainability of the functioning and development of the OOS largely determines the sustainability of the MTS [8].

The proposed concept of ensuring the sustainability of the MTS is based on a systematic approach. In accordance with this approach, the MTS is considered as a set of interacting subsystems-smaller systems. The functioning of each subsystem should be subject to the goals of the sustainable functioning and development of the entire system. The main conditions for the coordinated functioning of MTS subsystems are:

- Compliance with the system of principles as the governing rules for each subsystem of the system.

- Identification of the OOS as a key subsystem that has the greatest importance on the sustainability of the functioning and development of the MTS.

- Application of methods for assessing the sustainability of the functioning and development of the MTS subsystems.

The systematization of the principles of an MTS (Section 2.2) by the levels of their application in accordance with the proposed concept are presented in Table 2.

Sustainable development principles

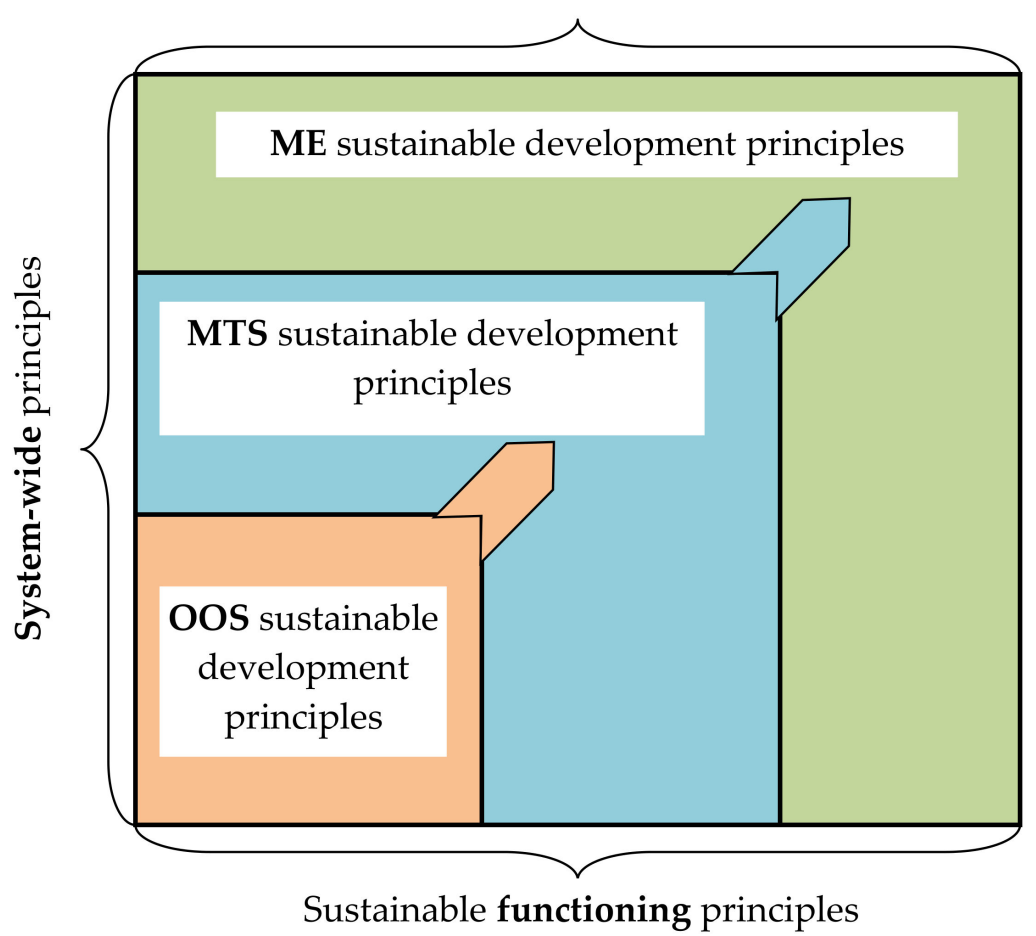

Figure 2. Concept for the implementation of mining and technical system sustainable functioning and development principles.

The systematization of the principles make it possible to reveal their preferential orientation towards achieving organizational and technological goals at the level of the MTS and ME. The absence of "social" and an insufficient number of "environmental" principles at the MTS level does not allow ensuring the environmental and social sustainability of this system and, consequently, reduces the overall sustainability of the MTS and ME. 
Table 2. Systematization of existing principles of mining enterprise according to the levels of their application.

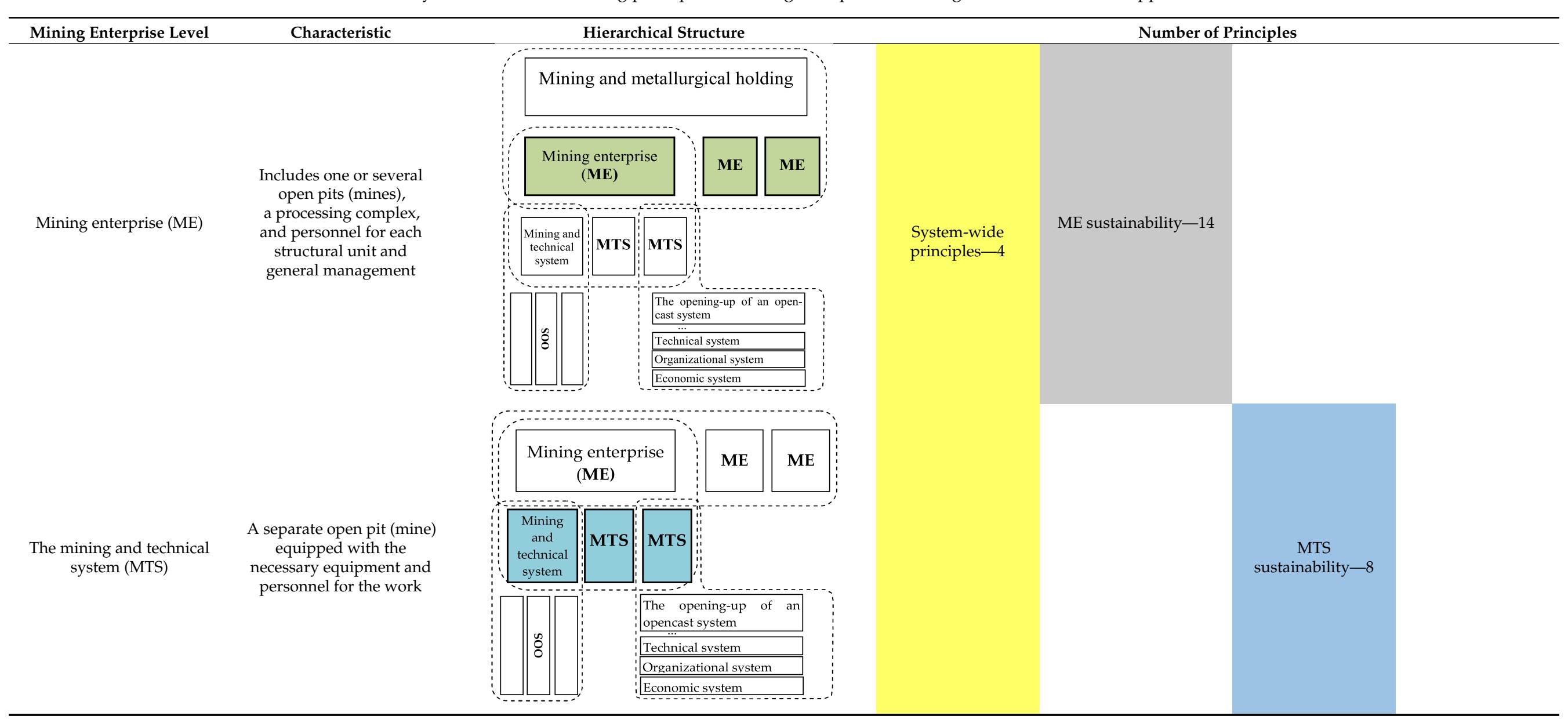


Table 2. Cont.

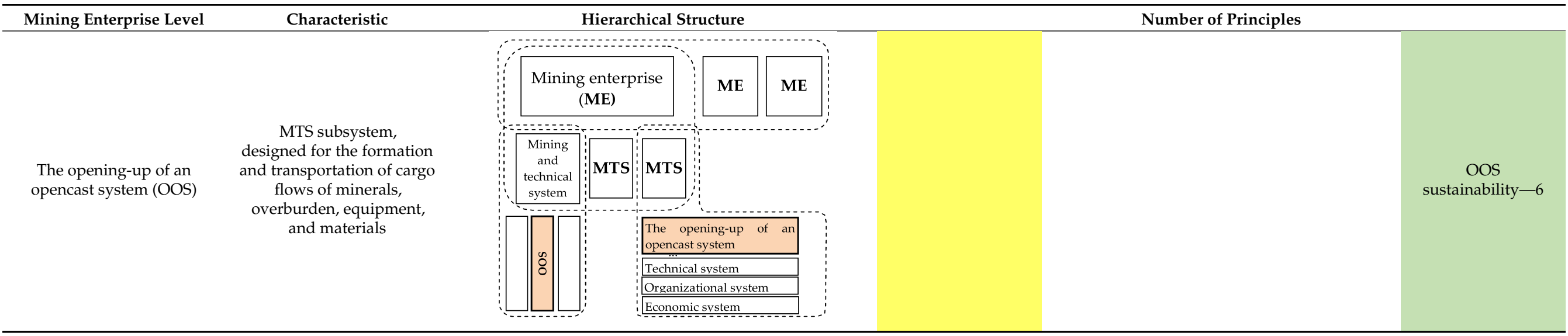

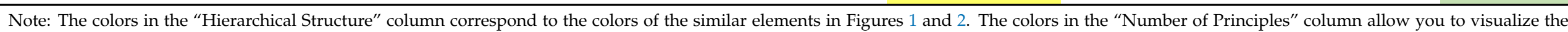
correspondence between the contents of the fourth and third columns. 


\subsection{System of the Mining and Technical System Sustainable Functioning and Development Principles in Transition Periods}

The authors suggest separating the concepts of "sustainable development" and "sustainable functioning" of the MTS to ensure the goals and objectives of sustainable development at all levels of management both within the MTS and in its interaction with the external environment.

Sustainable functioning of the MTS means the stable operation of the system over time with established technological (ore and overburden productivity) and economical design indicators after passing through transition periods. Sustainable functioning is ensured by optimizing the parameters of the opening system and the technical, technological, and organizational subsystems of the MTS. Sustainable development of the MTS expands the term of "sustainable functioning" and additionally considers changes in the social and environmental subsystems of the MTS during the transition period, as well as in subsequent stages of MTS operation and for the period after the completion of mining.

Mining enterprises extract minerals in established volumes in accordance with the projected development stage. An increase in the depth of mining operations leads to an increase in development costs, mainly in the OOS. Therefore, the decision to move to a new stage of development may occur during a period of decline in the overall efficiency of field development. The earlier a decision is made to start the transition period, the more alternatives exist for changing the OOS and MTS to ensure the sustainable functioning and development of the ME. Approaching the end of the next stage of development is associated with additional costs and other complicating factors characteristic of the transition period. As a result, the functioning of the MTS may become unstable. This can lead to a complete stop of the MTS operation.

Ensuring that the sustainable functioning and development of ME is based on the consistent and coordinated implementation of the relevant principles in the systems and subsystems of ME (Figure 2). In other words, the implementation of the principles of sustainable functioning and development for the OOS and other subsystems is the basis for the sustainability of the MTS, whereas the sustainability of ME is achieved by the implementation of the principles of sustainable operation and development of the MTS. Achievement of the goals of sustainable development of ME is carried out by aligning the goals of all subsystems of lower levels of management of goals and objectives of higher levels.

The proposed concept is used to systematize the existing principles (Section 2.2). The basis for systematization is the distribution of principles by levels of implementation (Figure 2): system-wide principles, principles of ME development, principles of development of the MTS, and principles of development of MTS subsystems, OOS. In addition, the existing principles are grouped according to aspects (factors) of sustainability: technical, technological, economic, environmental, and social (Table 3).

Table 3. System of principles for sustainable functioning and development of mining enterprise.

\begin{tabular}{|c|c|c|c|c|c|c|}
\hline \multirow{2}{*}{$\begin{array}{l}\text { Group of } \\
\text { Principles }\end{array}$} & \multirow{2}{*}{ Title of Principles } & \multicolumn{3}{|c|}{$\begin{array}{c}\text { Aspects (Factors) of } \\
\text { Sustainable Functioning }\end{array}$} & \multicolumn{2}{|c|}{$\begin{array}{l}\text { Aspects (Factors) of Sus- } \\
\text { tainable Development }\end{array}$} \\
\hline & & Technical & Technological & Economic & Environmental & Social \\
\hline \multirow{4}{*}{$\begin{array}{l}\text { System-wide } \\
\text { principles }\end{array}$} & Integrity & + & + & + & + & + \\
\hline & Structurality & + & + & + & + & + \\
\hline & Hierarchy & + & + & + & + & + \\
\hline & Controllability & + & + & + & + & + \\
\hline
\end{tabular}


Table 3. Cont

\begin{tabular}{|c|c|c|c|c|c|c|}
\hline \multirow{2}{*}{$\begin{array}{l}\text { Group of } \\
\text { Principles }\end{array}$} & \multirow{2}{*}{ Title of Principles } & \multicolumn{3}{|c|}{$\begin{array}{c}\text { Aspects (Factors) of } \\
\text { Sustainable Functioning }\end{array}$} & \multicolumn{2}{|c|}{$\begin{array}{l}\text { Aspects (Factors) of Sus- } \\
\text { tainable Development }\end{array}$} \\
\hline & & Technical & Technological & Economic & Environmental & Social \\
\hline \multirow{12}{*}{$\begin{array}{l}\text { Mining enterprises } \\
\text { development } \\
\text { principles }\end{array}$} & Development principles & + & + & + & & \\
\hline & Principles of modern mining & + & + & + & + & \\
\hline & $\begin{array}{c}\text { Principles of sustainable } \\
\text { development of geotechnology }\end{array}$ & & + & + & + & + \\
\hline & Methodological principles of mining planning & + & + & + & & \\
\hline & $\begin{array}{l}\text { Principles of macro-ecological risk mapping of } \\
\text { mining industry areas }\end{array}$ & & & + & + & + \\
\hline & Pit design principles & + & + & + & + & \\
\hline & Principles to mine waste management & & + & + & + & \\
\hline & Systemic flow-based principles in mining & + & + & + & & \\
\hline & Geometallurgy principles & & + & + & + & \\
\hline & $\begin{array}{l}\text { Principles of economic, environmental, and } \\
\text { socio-cultural sustainability }\end{array}$ & & + & + & + & + \\
\hline & $\begin{array}{l}\text { Mining operation principles } \\
\text { Principles of a methodological approach to }\end{array}$ & + & + & + & + & + \\
\hline & $\begin{array}{l}\text { solving } \\
\text { mining problems }\end{array}$ & + & + & + & + & \\
\hline \multirow{7}{*}{$\begin{array}{l}\text { Open pit mining } \\
\text { and technical } \\
\text { system } \\
\text { development } \\
\text { principles }\end{array}$} & $\begin{array}{l}\text { Principle of concurrent mining and } \\
\text { reclamation technology }\end{array}$ & & + & + & + & \\
\hline & $\begin{array}{c}\text { Principles of the full cycle of deposit } \\
\text { development }\end{array}$ & & + & + & + & + \\
\hline & MTS organization principles & + & + & + & & \\
\hline & MTS design principles & + & + & + & + & \\
\hline & $\begin{array}{l}\text { Principle for setting contours for open-pit } \\
\text { mining }\end{array}$ & & + & + & & \\
\hline & $\begin{array}{l}\text { Principles of ensuring the sustainability of } \\
\text { mining objects }\end{array}$ & & + & + & & \\
\hline & Control principle & & + & + & + & + \\
\hline \multirow{7}{*}{$\begin{array}{l}\text { Opening-up of an } \\
\text { opencast system } \\
\text { and other } \\
\text { subsystem's devel- } \\
\text { opment principles }\end{array}$} & $\begin{array}{l}\text { Principles of cyclic-flow technology in the } \\
\text { development of deep pits }\end{array}$ & + & + & + & & \\
\hline & $\begin{array}{l}\text { The principles of the formation of ore and } \\
\text { overburden flows, the principle of the OOS } \\
\text { scheme formation }\end{array}$ & + & + & + & & \\
\hline & $\begin{array}{l}\text { Transport operating principles } \\
\text { Principles for determining the moment of }\end{array}$ & + & + & + & & \\
\hline & $\begin{array}{l}\text { transition to a new mode of transport in the } \\
\text { development of deep quarries }\end{array}$ & + & + & + & & \\
\hline & $\begin{array}{l}\text { Principles of modeling of } \\
\text { excavator-truck-conveyor complexes }\end{array}$ & + & + & + & & \\
\hline & $\begin{array}{l}\text { The principles of deep quarries transport } \\
\text { systems formation }\end{array}$ & + & + & + & & \\
\hline & Based principles of high angle conveyors & + & + & & & \\
\hline
\end{tabular}

The use of the proposed system of principles is the basis for the effective functioning and sustainable development of ME. In addition, this system ensures the compliance of all systems and subsystems of ME with the goals of the concept of sustainable development and, as a result, ensures the achievement of the economic, environmental, and social goals of the functioning of ME.

\subsection{Opening-Up of an Opencast System Parameters and Indicators}

The implementation of the principles of sustainable operation and development of an MTS requires an assessment of the parameters and indicators of this system. In the previous sections, it was shown that the OOS is a key subsystem of the MTS. Therefore, the authors limited themselves to the study of the parameters and indicators of the OOS in this paper.

The complexity of assessing the functioning of the MTS and OOS lies in the insufficiently studied interrelationships of indicators and parameters of the MTS subsystems. Moreover, there are no methods for a comprehensive assessment of the set of parameters and indicators of OOS and its elements. The authors identified the following elements of the OOS: opening-up of an open-casts, transportation route and transportation construc- 
tion, vehicles, in-pit crusher (transshipment) points of rock mass, ore and overburden flows. The assessment of these elements is carried out using the parameters and indicators shown in Figure 3.

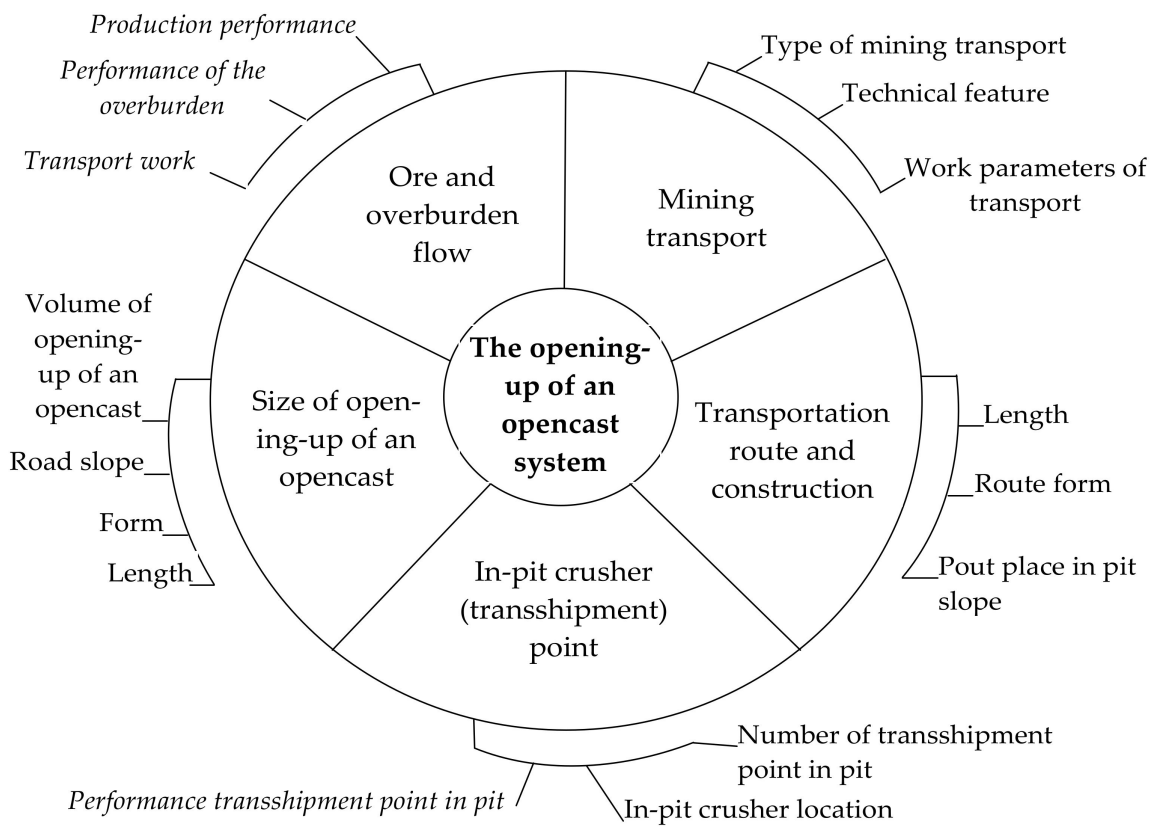

Figure 3. Elements, parameters, and indicators of the opening-up of an opencast system.

Systematization of MTS parameters and indicators is based on a functional approach. Five aspects (factors) of sustainable development have been identified: technical, technological, economic, social, and environmental. Each factor is assigned certain parameters and indicators (Table 4). The indicators are used to assess the interaction of the OOS with the MTS and the external environment. Indicators allow direct assessment of the OOS itself.

Table 4. System of parameters and indicators for evaluating the opening-up of an opencast system.

\begin{tabular}{|c|c|c|}
\hline $\begin{array}{l}\text { Aspects (Factors) of Sustainable } \\
\text { Functioning and Development }\end{array}$ & Parameters & Indicators \\
\hline Technical & Mining transport $(\mathrm{N})$ & $\begin{array}{l}\text { Mono transport (N1) } \\
\text { Combined transport (N2) }\end{array}$ \\
\hline Technological & $\begin{array}{c}\text { Performance of mining transport (QT) } \\
\text { Transport work (AT) } \\
\text { Volume of opening-up of an } \\
\text { opencast (V) }\end{array}$ & $\begin{array}{c}\text { Number of transport vehicles (QT1) } \\
\text { Performance of mining transport (QT2) } \\
\text { Number of transshipment points in pit (QT3) } \\
\text { Performance transshipment points in pit (QT4) } \\
\text { Transportation route length (AT1) } \\
\text { Height of rock mass transportation (AT2) } \\
\text { Traffic volume (AT3) } \\
\text { Height of opening-up (V1) } \\
\text { Width of opening-up (V2) } \\
\text { Length of opening-up (road slope) (V3) }\end{array}$ \\
\hline Economic & $\begin{array}{l}\text { Useful life of opening-up of an } \\
\text { opencast (T) } \\
\text { Economic efficiency (E) }\end{array}$ & $\begin{array}{l}\text { The duration of formation opening-up of an opencast (T1) } \\
\text { Mine period (T2) } \\
\text { Number of mine periods (T3) } \\
\text { Capital cost (E1) } \\
\text { Operating cost (E2) } \\
\text { Total income (E3) }\end{array}$ \\
\hline Social & Social efficiency (S) & $\begin{array}{c}\text { Working efficiency (S1) } \\
\text { Staff working conditions (S2) } \\
\text { Level of automation and robotization of the transportation } \\
\text { process (S3) }\end{array}$ \\
\hline Environmental & Environmental efficiency (EK) & $\begin{array}{c}\text { Air pollution (EK1) } \\
\text { Quantity of waste (EK2) }\end{array}$ \\
\hline
\end{tabular}


Management decisions on sustainable functioning and development of ME should be made considering compliance with the system of principles (Table 3). Evaluation of the effectiveness of the decisions made is carried out using the presented parameters and indicators (Table 4). The authors created the ranking of parameters and indicators-efficiency criteria using the fuzzy AHP.

\section{Ranking of Parameters and Indicators of the Opening-Up of an Opencast System for Sustainable Functioning and Development}

\subsection{Fuzzy AHP}

The hierarchy system of parameters and indicators of OOS includes two levels. The first level includes eight groups of parameters and the second level includes twentythree parameters and indicators (Table 4).

The triangular function [88] is used as a membership function in this study. Linguistic variables and triangular fuzzy numbers for assessing the parameters and indicators of OOS are presented in Table 5.

Table 5. Fuzzy and linguistic variables for evaluating parameters and indicators of the OOS.

\begin{tabular}{ccc}
\hline Fuzzy Number & Linguistic Term & Scale of Fuzzy Number \\
\hline 1 & Equal importance & $(1,1,3)$ \\
2 & Moderate superiority & $(1,3,5)$ \\
3 & Significant superiority & $(3,5,7)$ \\
4 & Strong superiority & $(5,7,9)$ \\
5 & Absolute superiority & $(7,9,10)$ \\
\hline
\end{tabular}

The ranking is carried out in four stages.

Stage 1. Construction of paired comparison matrices $\widetilde{A}\left(\widetilde{e}_{i j}\right)$ for all parameters and indicators of the MTS. This is necessary to determine the relative importance of each pair of parameters (indicators) among themselves.

$$
\widetilde{A}=\left[\begin{array}{cccc}
(1,1,1) & \widetilde{e}_{12} & \ldots & \widetilde{e}_{1 n} \\
\widetilde{e}_{21} & (1,1,1) & \ldots & \widetilde{e}_{2 n} \\
\ldots & \ldots & \ldots & \ldots \\
\widetilde{e}_{(n-1) 1} & \widetilde{e}_{(n-1) 2} & \ldots & \widetilde{e}_{(n-1) n} \\
\widetilde{e}_{n 2} & \widetilde{e}_{n 2} & \ldots & (1,1,1)
\end{array}\right]
$$

The judgment matrix, $\widetilde{A}$, is an $n \times n$ fuzzy matrix containing fuzzy numbers, $\widetilde{e}_{i j}$.

Stage 2. Determination of the value of the fuzzy synthetic extent, $S i$, relative to the $i$-th criterion

$$
\widetilde{e}_{i j}=\left\{\begin{array}{l}
1, i=j ; \\
9^{-1}, 8^{-1}, 7^{-1}, 6^{-1}, 5^{-1}, 4^{-1}, 3^{-1}, 2^{-1}, 1^{-1}, 1,2,3,4,5,6,7,8,9, i \neq j .
\end{array}\right.
$$

where

$$
\begin{gathered}
S_{i}=\sum_{j=1}^{m} \widetilde{e}_{i j}\left[\sum_{i=1}^{n} \sum_{j=1}^{m} \widetilde{e}_{i j}\right]^{-1} \\
\sum_{j=1}^{m} \widetilde{e}_{i j}=\left(\sum_{j=1}^{m} a_{j}, \sum_{j=1}^{m} b_{j}, \sum_{j=1}^{m} c_{j}\right) \\
{\left[\sum_{i=1}^{n} \sum_{j=1}^{m} \widetilde{e}_{i j}\right]^{-1}=\left(\frac{1}{\sum_{i=1}^{n} c_{i}}, \frac{1}{\sum_{i=1}^{n} b_{i}}, \frac{1}{\sum_{i=1}^{n} a_{i}}\right)}
\end{gathered}
$$


Stage 3. Calculation of the degree of possibility. The degree of possibility, $M_{2}=\left(a_{2}, b_{2}, c_{2}\right)>M_{1}=\left(a_{1}, b_{1}, c_{1}\right)$, is defined as

$$
\begin{gathered}
V\left(M_{2} \geq M_{1}\right)=\sup \left[\min \left(\mu_{M 1(x),} \mu_{M 2(y)}\right)\right]=\operatorname{hgt}\left(M_{1} \cap M_{2}\right)=\mu_{M 2(d)} \\
\mu_{M}(d)=\left\{\begin{array}{c}
1, \text { if } b_{2} \geq b_{1} \\
0, \text { if } a_{1} \geq c_{2} \\
\frac{a_{1}-c_{2}}{\left(b_{2}-c_{2}\right)-\left(b_{1}-a_{1}\right)} \text { otherwise }
\end{array}\right.
\end{gathered}
$$

where $d$ is the ordinate of the highest intersection point $D$ between $\mu_{M 1(x)}$ and $\mu_{M 2(y)}$.

The degree of the possibility for a convex fuzzy number is greater than $k$ convex fuzzy numbers, $M_{i}(i=1,2,3, \ldots, k)$, and is calculated by the formula

$$
V\left(M \geq M_{1}, M_{2}, \ldots, M_{k}\right)=V\left[\left(M \geq M_{1}\right),\left(M \geq M_{2}\right), \ldots,\left(M \geq M_{k}\right)\right] \ldots, k=\min V\left(M \geq M_{i}\right), i=1,2, \ldots, k
$$

The value $d^{\prime}\left(A_{i}\right)$ is calculated by the formula

$$
d^{\prime}\left(A_{i}\right)=\min V\left(S_{i} \geq S_{k}\right), \text { for } k=1,2, \ldots, n ; k \neq i
$$

Stage 4. Calculation of the weight vector and normalized weight vectors.

The weight vector is defined as

$$
W^{\prime}=\left(d^{\prime}\left(A_{1}\right), d^{\prime}\left(A_{2}\right), \ldots, d^{\prime}\left(A_{n}\right)\right)^{T}
$$

where $A_{i}(i=1,2,3, \ldots, n)$ is the vector of estimated parameters consisting of $n$ elements.

Via normalization, the normalized weight vectors are

$$
W=\left(d\left(A_{1}\right), d\left(A_{2}\right), \ldots, d\left(A_{n}\right)\right)^{T}
$$

where $W$ is the non-fuzzy number.

As a result of using the fuzzy AHP, the values of the weights of the parameters and indicators of the MTS will be obtained.

\subsection{Results}

Ten academic experts and ten representatives of mining industries were selected for questioning to assess the parameters and indicators of the MTS (Appendix A, Table A2). The questionnaires were processed using linguistic variables and triangular fuzzy numbers. Matrices of fuzzy aggregated estimates of MTS parameters and indicators are presented in Tables 6 and 7. The calculation results are shown in Figures 4-6.

Table 6. Final ranking parameters of opening-up of an opencast system.

\begin{tabular}{cccc}
\hline Parameters & \multicolumn{3}{c}{ Weight/Rank } \\
\cline { 2 - 4 } & Academic Experts & Mining Company Experts & $0.0915 /(6)$ \\
Mining transport (N) & $0.0603 /(8)$ & $0.1316 /(5)$ & $0.1709 /(2)$ \\
Performance of mining transport (QT) & $0.1594 /(2)$ & $0.1851 /(2)$ & $0.1217 /(4)$ \\
Transport work (AT) & $0.1109 /(5)$ & $0.1357 /(4)$ & $0.1233 /(3)$ \\
Volume of opening-up of an opencast (V) & $0.0821 /(6)$ & $0.1306 /(6)$ & $0.0993 /(5)$ \\
Useful life of opening-up of an opencast (T) & $0.0713 /(7)$ & $0.2487 /(1)$ & $0.2668 /(1)$ \\
Economic efficiency (E) & $0.2481 /(1)$ & $0.0047 /(7)$ & $0.0738 /(7)$ \\
Social efficiency (S) & $0.1527 /(3)$ & $0.0013 /(8)$ & $0.0527 /(8)$ \\
\hline Environmental efficiency (EK) & $0.1153 /(4)$ & &
\end{tabular}


Table 7. Final ranking indicators of opening-up of an opencast system.

\begin{tabular}{|c|c|c|c|c|c|c|}
\hline \multirow{2}{*}{ Indicators } & \multicolumn{3}{|c|}{ Weight/Rank } & \multicolumn{3}{|c|}{ Global Weight/Global Rank } \\
\hline & $\begin{array}{c}\text { Academic } \\
\text { Experts }\end{array}$ & $\begin{array}{l}\text { Mining } \\
\text { Company } \\
\text { Experts }\end{array}$ & Total & $\begin{array}{c}\text { Academic } \\
\text { Experts }\end{array}$ & $\begin{array}{l}\text { Mining } \\
\text { Company } \\
\text { Experts }\end{array}$ & Total \\
\hline Mono transport (N1) & $0.0789 /(2)$ & $0.1046 /(2)$ & $0.0934 /(2)$ & $0.0047 /(23)$ & $0.0137 /(16)$ & $0.0085 /(23)$ \\
\hline Combined transport (N2) & $0.9211 /(1)$ & $0.8954 /(1)$ & $0.9066 /(1)$ & $0.0555 /(4)$ & $0.1178 /(2)$ & $0.0829 /(2)$ \\
\hline Number of transport vehicles (QT1) & $0.1709 /(4)$ & $0.1451 /(3)$ & $0.1484 /(4)$ & $0.0273 /(16)$ & $0.0268 /(14)$ & $0.0254 /(19)$ \\
\hline Performance of mining transport (QT2) & $0.3120 /(1)$ & $0.5031 /(1)$ & $0.4145 /(1)$ & $0.0497 /(6)$ & $0.0931 /(3)$ & $0.07086 /(3)$ \\
\hline Number of transhipment points in pit (QT3) & $0.2833 /(2)$ & $0.0021 /(4)$ & $0.1520 /(3)$ & $0.0452 /(9)$ & $0.0004 /(23)$ & $0.0259 /(18)$ \\
\hline Performance transshipment points in pit (QT4) & $0.2337 /(3)$ & $0.3497 /(2)$ & $0.2852 /(2)$ & $0.0372 /(12)$ & $0.0647 /(5)$ & $0.0488 /(5)$ \\
\hline Transportation route length (AT1) & $0.2577 /(3)$ & $0.3632 /(2)$ & $0.3012 /(3)$ & $0.0286 /(17)$ & $0.0493 /(8)$ & $0.0367 /(9)$ \\
\hline Height of rock mass transportation (AT2) & $0.4301 /(1)$ & $0.2385 /(3)$ & $0.3158 /(2)$ & $0.0477 /(7)$ & $0.0324 /(13)$ & $0.0385 /(7)$ \\
\hline Traffic volume (AT3) & $0.3121 /(2)$ & $0.3983 /(1)$ & $0.3830 /(1)$ & $0.0346 /(14)$ & $0.0540 /(7)$ & $0.0466 /(6)$ \\
\hline Height of opening-up (V1) & $0.5073 /(1)$ & $0.4636 /(1)$ & $0.5030 /(1)$ & $0.0416 /(10)$ & $0.0753 /(4)$ & $0.0620 /(4)$ \\
\hline Width of opening-up (V2) & $0.1523 /(3)$ & $0.3746 /(2)$ & $0.2559 /(2)$ & $0.0125 /(22)$ & $0.0608 /(6)$ & $0.0315 /(15)$ \\
\hline Length of opening-up (road slope) (V3) & $0.3404 /(2)$ & $0.1617 /(3)$ & $0.2411 /(3)$ & $0.0279 /(18)$ & $0.0263 /(15)$ & $0.0297 /(16)$ \\
\hline The duration of formation opening-up of an opencast (T1) & $0.4502 /(1)$ & $0.2946 /(3)$ & $0.3596 /(2)$ & $0.0321 /(15)$ & $0.0385 /(11)$ & $0.0357 /(11)$ \\
\hline Mine period (T2) & $0.3570 /(2)$ & $0.3726 /(1)$ & $0.3619 /(1)$ & $0.0254 /(19)$ & $0.0487 /(9)$ & $0.0359 /(10)$ \\
\hline Number of mine periods (T3) & $0.1928 /(3)$ & $0.3327 /(2)$ & $0.2785 /(3)$ & $0.0137 /(21)$ & $0.0435 /(10)$ & $0.0277 /(17)$ \\
\hline Capital cost $(\mathrm{E} 1)$ & $0.1835 /(2)$ & $0.0499 /(3)$ & $0.1256 /(3)$ & $0.0455 /(8)$ & $0.0124 /(17)$ & $0.0335 /(14)$ \\
\hline Operating cost (E2) & $0.1412 /(3)$ & $0.1384 /(2)$ & $0.1403 /(2)$ & $0.0350 /(13)$ & $0.0344 /(12)$ & $0.0374 /(8)$ \\
\hline Total income (E3) & $0.6753 /(1)$ & $0.8117 /(1)$ & $0.7340 /(1)$ & $0.1676 /(1)$ & $0.2019 /(1)$ & $0.1958 /(1)$ \\
\hline Working efficiency (S1) & $0.3551 /(2)$ & $0.3246 /(2)$ & $0.3347 /(2)$ & $0.0542 /(5)$ & $0.0015 /(19)$ & $0.0247 /(20)$ \\
\hline Staff working conditions (S2) & $0.4986 /(1)$ & $0.4194 /(1)$ & $0.4688 /(1)$ & $0.0761 /(3)$ & $0.0019 /(18)$ & $0.0346 /(12)$ \\
\hline $\begin{array}{c}\text { Level of automation and robotization of the } \\
\text { transportation process (S3) }\end{array}$ & $0.1463 /(3)$ & $0.2560 /(3)$ & $0.1965 /(3)$ & $0.0223 /(20)$ & $0.0012 /(20)$ & $0.0145 /(22)$ \\
\hline Air pollution (EK1) & $0.6762 /(1)$ & $0.5988 /(1)$ & $0.6413 /(1)$ & $0.0779 /(2)$ & $0.0008 /(21)$ & $0.0338 /(13)$ \\
\hline Quantity of waste (EK2) & $0.3238 /(2)$ & $0.4012 /(2)$ & $0.3587 /(2)$ & $0.0373 /(11)$ & $0.0005 /(22)$ & $0.0189 /(21)$ \\
\hline
\end{tabular}

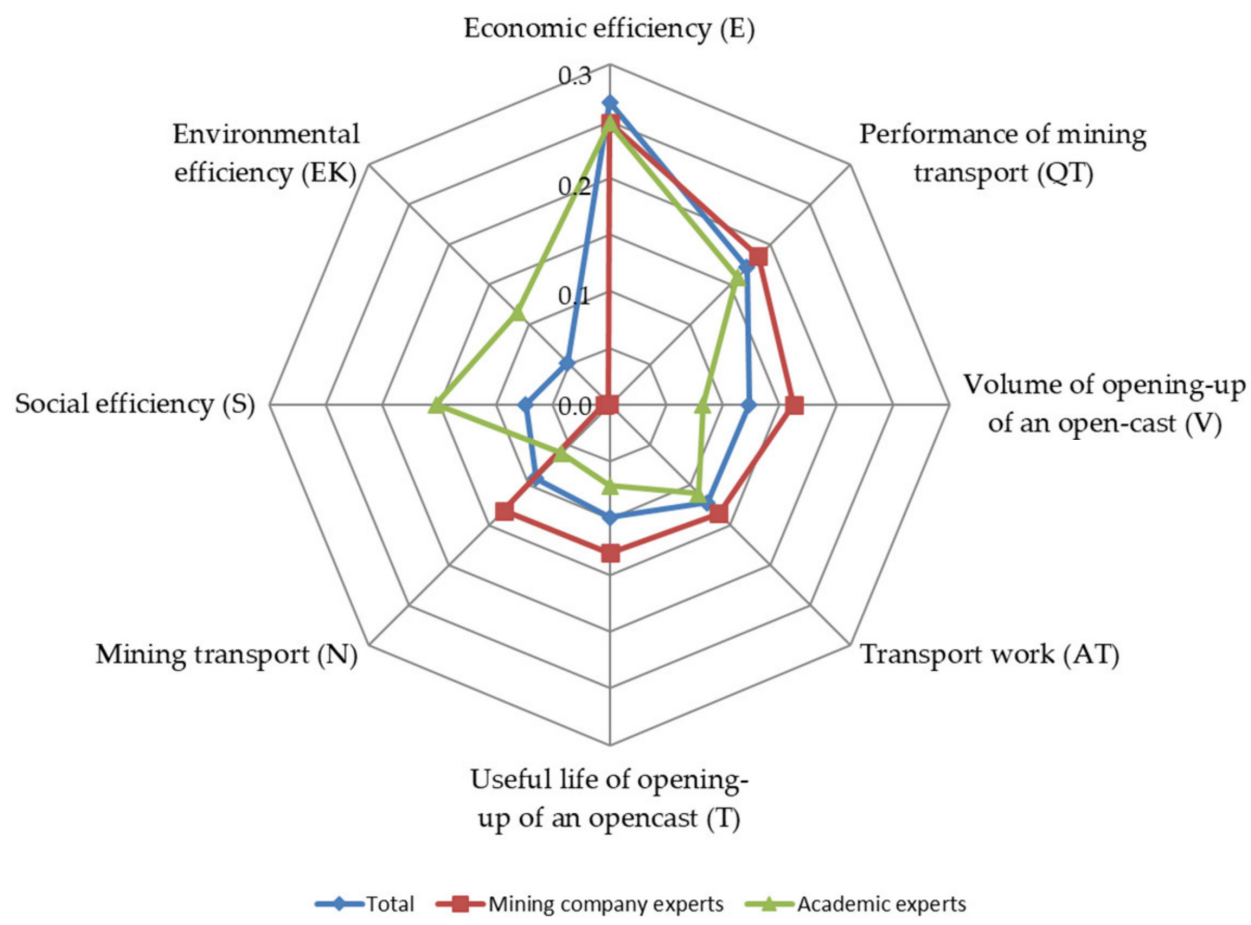

Figure 4. Ranking of opening-up of an opencast system parameters. 


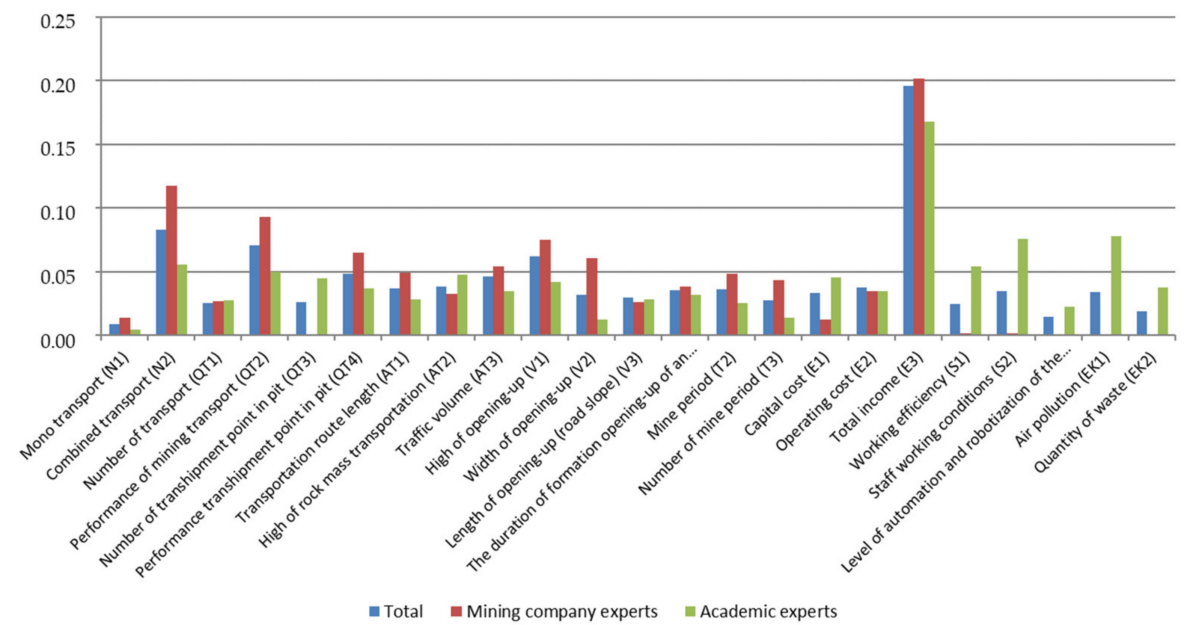

Figure 5. Ranking of opening-up of an opencast system indicators.

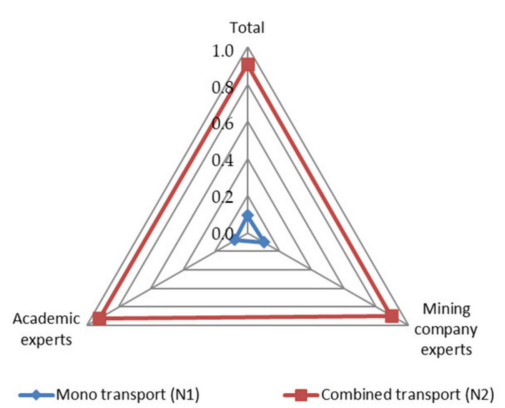

(a)

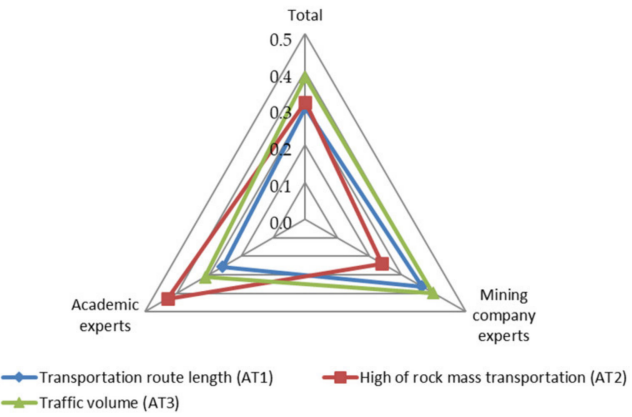

(c)

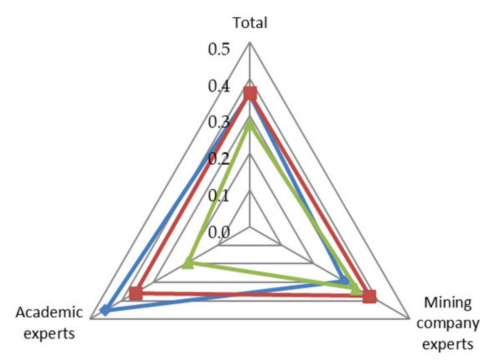

$\rightarrow$ The duration of formation opening-up of an opencast (T1) $\rightarrow-$ Mine period (T2)

(e)

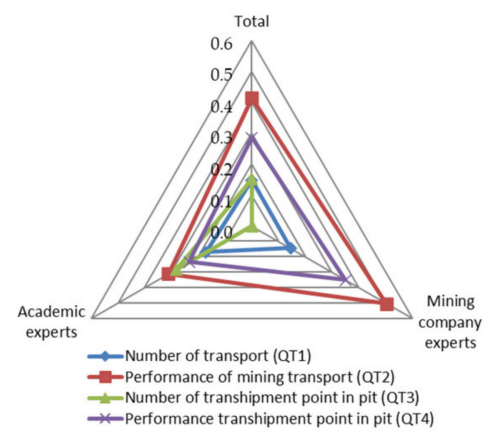

(b)

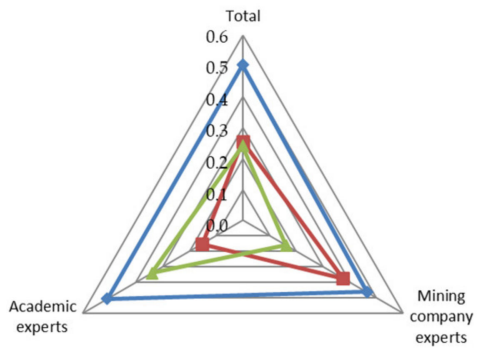

- High of opening-up (V1) -Length of opening-up (road slope) (V3)

(d)

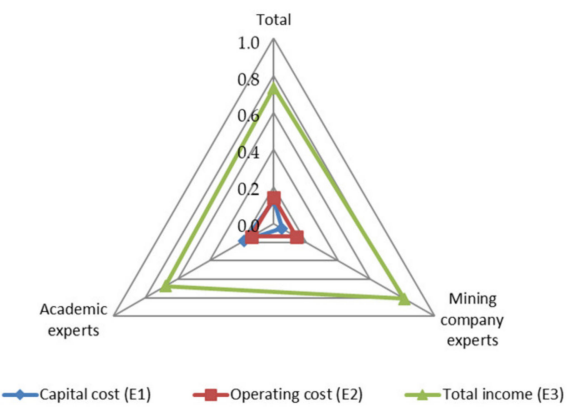

(f)

Figure 6. Cont. 


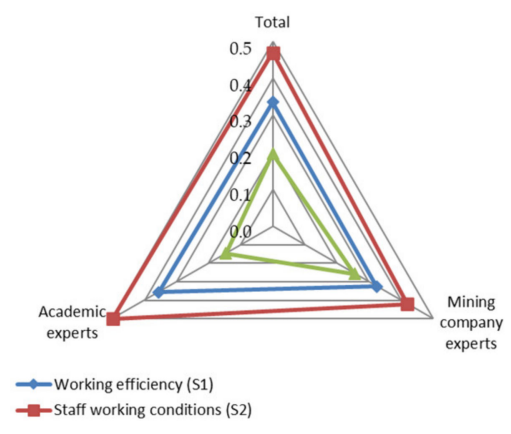

(g)

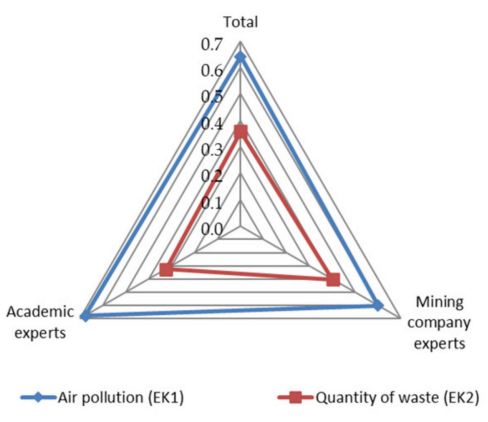

(h)

Figure 6. Ranking of opening-up of an opencast system indicators: (a) Mining transport; (b) Performance of mining transport; (c) Transport work; (d) Volume of opening-up of an opencast; (e) Useful life of opening-up of an opencast; (f) Economic efficiency; (g) Social efficiency; (h) Environmental efficiency.

The results of evaluating groups of parameters (Figure 5) show a fairly high convergence of expert opinions regarding the significance of the following parameters: economic efficiency, $\mathrm{E}=0.24812$, rank $=1$ (academic experts) and $\mathrm{E}=0.24870$, rank $=1$ (mining company experts); career transport performance, $\mathrm{QT}=0.15939$, rank $=2$ (academic experts) and QT $=0.18514$, rank $=2$ (mining company experts).

The greatest divergence of opinions among experts occurs regarding social (S) and environmental (EK) efficiency. Mining company experts assigned these parameters the smallest values, $\mathrm{S}=0.00471$, rank $=7$ and $\mathrm{EK}=0.00129$, rank $=8$. On the contrary, the assessment of these parameters by academic experts is high, $\mathrm{S}=0.15269$, rank $=3$ and $\mathrm{EK}=0.11528$, rank $=4$.

The results of ranking the OOS indicators (Figure 6) show a significant superiority of economic efficiency (total income) (E3). This indicator is ranked first by all expert groups. Comparisons of OOS indicator assessments by academic and mining company experts show the greatest convergence of opinions by indicators: total income, $\mathrm{E} 3=0.1676$, rank $=1$ (academic experts) and E3 $=0.2019$, rank $=1$ (mining company experts); combined transport, $\mathrm{N} 2=0.0555$, rank $=4$ (academic experts) and N2 $=0.1178$, rank $=2$ (mining company experts).

The worst convergence of expert opinions are on the following indicators: air pollution, $\mathrm{EK} 1=0.0779$, rank $=2$ (academic experts) and EK1 $=0.0008$, rank $=21$ (mining company experts); staff working conditions, S2 $=0.0761$, rank $=3$ (academic experts) and S2 $=0.0019$, rank $=18$ (mining company experts).

The results of ranking the parameters and indicators of the OOS showed the greatest significance of the parameters: economic efficiency (E), performance of mining transport (QT), and the volume of opening-up of an opencast (V). The most significant indicators are total income (E3), combined transport (N2), and performance of mining transport (QT2). There is a significant difference in the assessments of academic experts and mining industry representatives regarding social and environmental parameters and indicators. Mining industry representatives ranked these parameters and indicators as least significant. This suggests that managerial decisions to optimize the OOS and the MTS for enterprises are primarily aimed at achieving sustainable functioning of ME. On the other hand, academics experts consider it more important to achieve sustainable development goals.

\section{Conclusions}

The literature review showed a lack of research on the relationship of parameters and indicators between the subsystems of the mining and technical system (MTS). Moreover, there are no methods for a comprehensive assessment of numerous parameters and indicators of the mining and technical system and its elements. This is the reason 
for both the difficult assessment of the functioning of the mining and technical system and the opening-up of an opencast system (OOS), and the managerial decision making.

The paper analyzes the factors of sustainable functioning and development of an MTS. It has been proven that the opening-up of an opencast system has the greatest impact on MTS efficiency and should be considered as a priority subsystem. The systematization of the parameters and indicators of the OOS was carried out based on a functional approach and the allocation of five groups of factors (aspects of sustainable functioning and development): technical, technological, economic, social, and environmental. A two-level hierarchical assessment of factors is proposed using eight groups of parameters (first level) and twenty-three parameters and indicators (second level). The first level of the hierarchy considers the parameters for assessing the OOS when interacting with the MTS and the external environment. The second level of the hierarchy includes specific parameters and indicators of the functioning of the OOS. Fuzzy AHP for ranking parameters and indicators of the OOS is justified. The developed methodology and the results of assessing the sustainable functioning and development of the OOS using the fuzzy AHP method are presented.

The results of the assessment and ranking of the parameters and indicators of the MTS showed:

- The most significant groups of parameters (rank more than 0.1) are established: economic efficiency (E), performance of mining transport (QT), and the volume of opening-up of an opencast $(\mathrm{V})$. The most significant parameters and indicators of the OOS (rank more than 0.07): total income (E3), combined transport (N2), and performance of mining transport (QT2). The greatest divergence of opinions between academic and industrial experts is observed on groups of parameters: social efficiency (S) and environmental efficiency (EK).

- The least significant indicators of the opening system, according to experts, are mono transport in the quarry (N1), the level of automation and robotization of the transportation process (S3), and quantity of waste (EK2). The listed indicators are included in the groups of parameters that have a low rating rank.

- Three groups of indicators were identified as a result of ranking: with a weight from 0.195 to 0.048 (rank 1-5), with a weight from 0.046 to 0.029 (rank 6-16), and with a weight below 0.029 (rank 17-23). The first group includes one economic (E3), one technical (N2), and three technological (QT2, QT4, V1) indicators of the MCS. The second group consists of five technological (AT1, AT2, AT3, V2, V3), four economic (E1, E2, T1, T2), one social (S2), and one environmental (EK1) indicators. The third group is represented by two technological (QT1, QT3), two social (S1, S3), one technical (N1), one economic (T3), and one environmental (EK2) indicators.

The results of ranking the parameters and indicators of the OOS showed the priority of economic, technological, and technical factors over environmental and social factors when making management decisions. This testifies to the predominance of the goals of sustainable functioning in management practice. The sustainable development of the MTS and the OOS should be based on a comprehensive assessment of the technical, technological, economic, environmental, and social aspects of sustainable development. Economic indicators are used to manage both the process of sustainable operation and the sustainable development of the MTS and its subsystems. The priority of economic indicators ensures exclusive profit and economic sustainability. However, ignoring environmental and social indicators does not allow the MTS and its subsystems to achieve sustainable development goals.

A concept and a system of principles for sustainable functioning and development of the MTS in transition periods have been developed. The implementation of the concept and the system of principles ensures the coordination of the economic goals of the MTS subsystems with goals in the fields of social development of ME and environmental protection. The existing principles of design and development of mining production are grouped in accordance with the levels of management of ME and the MTS into four 
groups: system-wide principles, mining enterprise development principles, principles of development of the MTS, and the opening-up of an opencast system and other subsystem development principles. In addition, the grouping considered the factors (aspects) of the sustainable functioning and development of the MTS: technical, technological, economic, environmental, and social.

The research performed can be useful for open pit mines. The use of the proposed technique is especially relevant for deep open pit mines. These open pit mines are developed in several stages. Each stage is characterized by numerous possible options for the development of the OOS. The main advantages of the proposed approach to the assessment of the OOS: achieving objectivity in the assessment of OOS elements for compliance with the requirements of the concept of sustainable development; ensuring the validity of design, strategic, and operational decisions based on the alignment of economic goals with goals in the fields of ecology and social development MTS.

Future research involves the use of combined multi-criteria decision making methods (MCMDs) to select the development option for the OOS and the MTS, considering the conditions for the functioning of ME. A combination of Analytic Network Process (ANP) and the Technique for Order of Preference by Similarity to Ideal Solution (TOPSIS) is proposed. Using ANP allows for consideration of the dependencies and feedbacks between the parameters and indicators of the MTS. TOPSIS is supposed to be used to select the most effective option for the sustainable development of the MTS.

Author Contributions: Conceptualization, A.R., K.B., and N.O.; methodology, K.B. and N.O.; validation, A.R., K.B., and N.O.; formal analysis, K.B. and N.O.; investigation, K.B. and N.O.; data curation, K.B.; writing-original draft preparation, K.B. and N.O.; writing-review and editing, A.R.; visualization, A.R., K.B., and N.O.; project administration, A.R. All authors have read and agreed to the published version of the manuscript.

Funding: This research received no external funding.

Institutional Review Board Statement: Not applicable.

Informed Consent Statement: Not applicable.

Data Availability Statement: Not applicable.

Conflicts of Interest: The authors declare no conflict of interest.

\section{Appendix A}

Table A1. List of abbreviations. The abbreviations including in the text are reported alphabetically.

\begin{tabular}{cll}
\hline Abbreviation & \multicolumn{1}{c}{ Full Form } & \multicolumn{1}{c}{ Definition } \\
\hline AHP & The Analytic hierarchy process & $\begin{array}{l}\text { AHP is a structured technique for organizing and } \\
\text { analyzing complex decisions based on mathematics and } \\
\text { psychology, developed by Thomas Saaty in the 1970s. }\end{array}$ \\
ANP & The Analytic Network Process & $\begin{array}{l}\text { ANP is a multi-criteria theory of measurement used to } \\
\text { derive relative priority scales of absolute numbers from } \\
\text { individual judgments (or from actual measurements } \\
\text { normalized to a relative form) that also belong to a } \\
\text { fundamental scale of absolute numbers. }\end{array}$ \\
\hline MCDM & $\begin{array}{l}\text { MCDM is a sub-discipline of operations research that } \\
\text { explicitly evaluates multiple conflicting criteria in } \\
\text { decision making. }\end{array}$ \\
\hline ME & The Mining Enterprise & $\begin{array}{l}\text { ME is a mining enterprise that independently mines and } \\
\text { processes minerals. }\end{array}$ \\
\hline
\end{tabular}


Table A1. Cont.

\begin{tabular}{|c|c|c|}
\hline Abbreviation & Full Form & Definition \\
\hline MTS & The Mining and Technical System & $\begin{array}{l}\text { MTS is a combination of mining structures, open and } \\
\text { underground technical and technological subsystems, } \\
\text { physicochemical and special mining methods in } \\
\text { interaction with the enclosing subsoil areas. }\end{array}$ \\
\hline OOS & The Opening-Up of An Opencast System & $\begin{array}{l}\text { OOS is defined by the authors as a complex technical } \\
\text { and technological subsystem of the mining and technical } \\
\text { system, designed for the formation and transportation } \\
\text { of freight flows of minerals, overburden, equipment, } \\
\text { and materials, consisting of opening workings, mining } \\
\text { transport, and devices, as well as in-pit crasher } \\
\text { (transshipment) points of rock mass. }\end{array}$ \\
\hline TOPSIS & $\begin{array}{l}\text { The Technique for Order of Preference by } \\
\text { Similarity to Ideal Solution }\end{array}$ & $\begin{array}{l}\text { TOPSIS is a method of compensatory aggregation that } \\
\text { compares a set of alternatives by identifying weights for } \\
\text { each criterion, normalizing scores for each criterion and } \\
\text { calculating the geometric distance between each } \\
\text { alternative and the ideal alternative, which is the best } \\
\text { score in each criterion. }\end{array}$ \\
\hline
\end{tabular}

Table A2. Information about the experts.

\begin{tabular}{|c|c|c|c|c|}
\hline No. & Academic Degree & Number of Experts & Expert Science Interests & $\begin{array}{l}\text { Work Experience in } \\
\text { the Field of Research }\end{array}$ \\
\hline \multicolumn{5}{|c|}{ Academic experts } \\
\hline \multirow{2}{*}{1} & \multirow{2}{*}{ Professor, Doctor (Technical Science) } & 2 & Geotechnology, design of mining systems & 41 \\
\hline & & 2 & Industrial transport, logistics & 34 \\
\hline \multirow{2}{*}{2} & \multirow{2}{*}{ Assistant Professor (PhD) } & 4 & Geotechnology, design of mining systems & $16-17$ \\
\hline & & 2 & $\begin{array}{l}\text { Industrial transport, logistics, } \\
\text { geotechnology }\end{array}$ & 19 \\
\hline \multicolumn{5}{|c|}{ Mining industry representatives } \\
\hline 3 & Senior leadership (PhD) & 1 & Iron ore mining & 15 \\
\hline 4 & Top management & 3 & Copper ore mining & $5-9$ \\
\hline 5 & $\begin{array}{l}\text { Top management, } \\
\text { Senior leadership }\end{array}$ & 3 & Diamond and other minerals mining & $7-10$ \\
\hline 6 & $\begin{array}{l}\text { Top management, } \\
\text { Senior leadership }\end{array}$ & 2 & $\begin{array}{c}\text { Mine design, automation of mining } \\
\text { operations }\end{array}$ & $10-14$ \\
\hline 7 & Senior leadership (PhD) & 1 & $\begin{array}{c}\text { Mine design, automation of mining } \\
\text { operations }\end{array}$ & 35 \\
\hline
\end{tabular}

\section{References}

1. Abdollahisharif, J.; Bakhtavar, E.; Shahriar, K. Open-pit to underground mining - Where is the optimum transition depth? In New Challenges and Visions for Mining-21st World Mining Congress; Sobczyk, J., Kicki, J., Eds.; Taylor \& Francis: London, UK, 2008; pp. 189-196, ISBN 978-0-415-48667-5.

2. Phlevani, D.; Osanloo, M. Resumption of Deep Open-Pit Mining as a Future Challenge May. In Application of Computers and Operations Research in the Mineral Industry; Bandopadhyay, S., Ed.; Society for Mining Metallurgy and Exploration Inc.: Englewood, CO, USA, 2015; pp. 249-256, ISBN 0-8733-5417-6.

3. Paricheh, M.; Osanloo, M. Determination of the optimum in-pit crusher location in open-pit mining under production and operating cost uncertainties. In Proceedings of the 16th International Conference on Computer Applications in the Mineral Industries (CAMI 2016), Istanbul, Turkey, 5-7 October 2016; p. 34.

4. Czaplicki, J.M. Shovel-Truck Systems: Modelling, Analysis and Calculation; CRC Press: Boca Raton, FL, USA, 2009; p. 172, ISBN 978041-548-135-9.

5. Burmistrov, K.V.; Osintsev, N.A.; Shakshakpaev, A.N. The Selection of Open-pit Dump Trucks at the Reconstruction of Quarry. Proc. Eng. 2017, 206, 1696-1702. [CrossRef]

6. Shrivastava, P.; Vidhi, R. Pathway to Sustainability in the Mining Industry: A Case Study of Alcoa and Rio Tinto. Resources 2020, 9, 70. [CrossRef]

7. Kaplunov, D.R.; Ryl'nikova, M.V. Principles of projecting mining-and-engineering systems for integrated mineral mining with a combined geotechnology. J. Min. Sci. 2008, 44, 578-584. [CrossRef] 
8. Burmistrov, K.V.; Osintsev, N.A. Principles of sustainable development of mining and technical systems in transitional periods. Bull. Tomsk. Polytec. Univ. Geo Assets Eng. 2020, 331, 179-195. [CrossRef]

9. Bascetin, A. A decision support system using analytical hierarchy process (AHP) for the optimal environmental reclamation of an open-pit mine. Environ. Geol. 2007, 52, 663-672. [CrossRef]

10. Samanta, B.; Sarkar, B.; Mukherjee, S.K. Selection of opencast mining equipment by a multi-criteria decision-making process Min. Technol. 2013, 111, 136-142. [CrossRef]

11. Yutyaev, A.V. Comprehensive Substantiation of the Parameters of Mining Systems of High-Performance Coal Mines. PhD Thesis, MISiS, Moscow, Russia, 2017; p. 129. (In Russian)

12. Yakovlev, V.L.; Glebov, A.V.; Kulniyaz, S.S.; Karmaev, G.D. Comparative analysis of the application of steep conveyor lines on quarries. Ser. Geol. Tech. Sci. 2020, 3, 88-96. [CrossRef]

13. Yazdani-Chamzini, A. An integrated fuzzy multi criteria group decision making model for handling equipment selection. J. Civ. Eng. Manag. 2014, 20, 660-673. [CrossRef]

14. Kursunoglu, N.; Onder, M. Selection of an appropriate fan for an underground coal mine using the Analytic Hierarchy Process Tunn. Undergr. Space Technol. 2015, 48, 101-109. [CrossRef]

15. Lashgari, A.; Yazdani-Chamzini, A.; Fouladgar, M.M.; Zavadskas, E.K.; Shafiee, S.; Abbate, N. Equipment selection using fuzzy multi criteria decision making model: Key study of Gole Gohar Iron Min. Eng. Econ. 2012, 23, 125-136. [CrossRef]

16. Dey, P.K.; Ramcharan, E.K. Analytic hierarchy process helps select site for limestone quarry expansion in Barbados. J. Environ. Manag. 2008, 88, 1384-1395. [CrossRef] [PubMed]

17. Soofastaei, A.; Aminossadati, S.M.; Kizil, M.; Knights, P. Reducing Fuel Consumption of Haul Trucks in Surface Mines Using Artificial Intelligence Models. In Proceedings of the 16th Coal Operators' Conference, Mining Engineering, Wollongong, NSW, Australia, 10-12 February 2016; pp. 477-489.

18. Vuyeykova, O.N.; Larin, O.N. The problem of enhancing the effectiveness of the career of motor transport. Vestnik Orenburg State Univ. 2011, 10, 20-25. (In Russian)

19. Adebimpe, R.A.; Akande, J.; Arum, C. Mine equipment selection for Ajabanoko Iron Ore Deposit, Kogi State, Nigeria. Sci. Res. 2013, 1, 25-30. [CrossRef]

20. Golik, V.I.; Khasheva, Z.M.; Shulgatyi, L.P. Economical efficiency of utilization of allied mining enterprises waste. Soc. Sci. 2015, 10, 750-754. [CrossRef]

21. Altushkin, I.A.; Cherepovitsyn, A.E.; Korol, Y.A. Practical Realization of Sustainable Development Mechanism in Foundation and Development of Mining and Metallurgical Holding of Russian Copper Industry; Ore and Metals: Moscow, Russia, 2016; 232p, ISBN 978-5-98191-082-1. (In Russian)

22. EBRD Extractive Mining Industries Strategy 2018-2022. Available online: https:/ /www.ebrd.com/documents/natural-resources / mining-operations-policy.pdf (accessed on 22 December 2020).

23. Shen, L.; Muduli, K.; Barve, A. Developing a sustainable development framework in the context of mining industries: AHP approach. Resour. Policy 2015, 46, 15-26. [CrossRef]

24. Transforming Our World: The 2030 Agenda for Sustainable Development. Available online: https://sdgs.un.org/publications/ transforming-our-world-2030-agenda-sustainable-development-17981 (accessed on 10 December 2020).

25. Rakhmangulov, A.; Sladkowski, A.; Osintsev, N.; Muravev, D. Green logistics: A system of methods and instruments. Part 2. Nase More 2018, 65, 49-55. [CrossRef]

26. Hustrulid, W.A.; Kuchta, M.; Martin, R. Open Pit Mine Planning and Design, 3rd ed.; CRC Press: Boca Raton, FL, USA; Taylor \& Francis Group: Milton, UK, 2013; ISBN 978-1-4822-2117-6.

27. Khokhryakov, B.C. Open Pit Design; Nedra: Moscow, Russia, 1992; 383p, ISBN 5-247-01721-8. (In Russian)

28. Suprun, V.; Agafonov, J. Substantiation of Boundaries and Procedure for Mining of Large Coal Brachysynclines. In Mine Planning and Equipment Selection; Drebenstedt, C., Singhal, R., Eds.; Springer International Publishing: Cham, Switzerland, 2014; pp. 25-29. [CrossRef]

29. Jeswiet, J. Including towards sustainable mining in evaluating mining impacts. Procedia CIRP 2017, 62, 494-499. [CrossRef]

30. Morteza, O.; Mahdi, R. Mine Design Selection Considering Sustainable Development. In Mine Planning and Equipment Selection; Drebenstedt, C., Singhal, R., Eds.; Springer International Publishing: Berlin/Heidelberg, Germany, 2014. [CrossRef]

31. Molotilov, S.G.; Cheskidov, V.I.; Norri, V.K. Methodical principles for planning the mining and loading equipment capacity for open cast mining with the use of dumpers. Part I. J. Min. Sci. 2008, 44, 376-385. [CrossRef]

32. Ramani, R.V. Surface mining technology: Progress and prospects. Proc. Eng. 2012, 46, 9-21. [CrossRef]

33. Kalabin, G.V. Principles of macro-ecological risk mapping of mining industry areas. J. Min. Sci. 2012, 48, 1071-1078. [CrossRef]

34. Williams, D.J. Applying geomechanics principles to mine waste management. In Proceedings of the 7th International Congress on Environmental Geotechnics (ICEG2014), Melbourne, VIC, Australia, 10-14 November 2014; Engineers Australia: Canberra, ACT, Australia; pp. 198-205.

35. Chen, J.-H.; Gu, D.-S.; Li, J.-X. Optimization principle of combined surface and underground mining and its applications. J. Cent. South Univ. Technol. 2003, 10, 222-225. [CrossRef]

36. Claassen, J.O. Application of systemic flow-based principles in mining. J. S. Afr. Inst. Min. Metall. 2015, 115, 747-754. [CrossRef]

37. Dominy, S.; O'Connor, L.; Parbhakar-Fox, A. Geometallurgy-A route to more resilient mine operations. Minerals 2018, 8, 560. [CrossRef] 
38. Mining Principles. Available online: https://www.icmm.com/mining-principles (accessed on 24 November 2020).

39. Sinan Erzurumlu, S.; Erzurumlu, Y.O. Sustainable mining development with community using design thinking and multi-criteria decision analysis. Resour. Policy 2015, 46, 6-14. [CrossRef]

40. Fraser, J. Creating shared value as a business strategy for mining to advance the United Nations Sustainable Development Goals. Extr. Ind. Soc. 2019, 6, 788-791. [CrossRef]

41. Mills, T. Fully armed: Is the application of the arm's length principle the best method to address transfer mispricing in the mining industry in developing countries? Extr. Ind. Soc. 2019, 6, 1075-1078. [CrossRef]

42. Makumbe, S.; Hattingh, T.; Plint, N.; Esterhuizen, D. Effectiveness of using Learning Factories to impart Lean principles in mining employees. Proc. Manuf. 2018, 23, 69-74. [CrossRef]

43. Mancini, L.; Sala, S. Social impact assessment in the mining sector: Review and comparison of indicators frameworks. Resour. Policy 2018, 57, 98-111. [CrossRef]

44. Yakovlev, V.L.; Sokolov, I.V.; Sakantsev, G.G.; Kravchuk, I.L. Transition processes in hybrid mineral mining. Gornyi Zhurnal 2017, 7, 46-50. [CrossRef]

45. Hu, Z.; Xiao, W.; Fu, Y. Introduction to Concurrent Mining and Reclamation for Coal Mines in China. In Mine Planning and Equipment Selection; Drebenstedt, C., Singhal, R., Eds.; Springer International Publishing: Cham, Switzerland, 2014; pp. 781-790. [CrossRef]

46. Lapaev, V.N.; Pikalov, V.A. Principles of designing high-performance mining and technical systems of quarries. Min. Inf. Anal. Bull. 2011, S11, 429-435. (In Russian)

47. Gavrishev, S.E.; Zoteev, O.V.; Zalyadnov, V.Y. Slope stability assessment, considering underground mining of ore reserves in open pit walls and floor at Sibay deposit. Gornyi Zhurnal 2016, 5, 53-58. [CrossRef]

48. Fleurisson, J.-A. Slope design and implementation in open pit mines: Geological and geomechanical approach. Proc. Eng. 2012, 46, 27-38. [CrossRef]

49. Baranov, E.G.; Tangaev, I.A. Energy principles for analysis and optimization of mining and ore preparation processes. Sov. Min. Sci. 1989, 25, 334-345. [CrossRef]

50. Wang, Q.; Zhang, Y.; Chen, C.; Xu, W. Open-pit mine truck real-time dispatching principle under macroscopic control. In Proceedings of the First International Conference on Innovative Computing, Information and Control—Volume I, ICICIC'06, Beijing, China, 30 August-1 September 2006; pp. 702-706. [CrossRef]

51. Bukeikhanova, S.; Kulniyaz, S.; Lysenko, S. Principles of cyclic-flow technology in the development of deep pits. In Mine Planning and Equipment Selection; Drebenstedt, C., Singhal, R., Eds.; Springer International Publishing: Berlin/Heidelberg, Germany, 2014; pp. 65-73. [CrossRef]

52. Rzhevsky, V.V. Part 2. Technology and Integrated Mechanization. In Open Pit Mining: Book for Universities; Nedra: Moscow, Russia, 1985; p. 549. (In Russian)

53. Yakovlev, V.L. Theory and Practice of Transport Choice of Deep Quarries; Science: Novosibirsk, Russia, 1989; p. 240. (In Russian)

54. Mahdi, R.; Morteza, O. Determining the Most Effective Factors on Open Pit Mine Plans and Their Interactions. In Mine Planning and Equipment Selection; Drebenstedt, C., Singhal, R., Eds.; Springer International Publishing: Berlin/Heidelberg, Germany, 2014; pp. 197-207. [CrossRef]

55. Khazin, M.L. Robotic Equipment for Mining Operations. Vestnik Nosov Magnitogorsk State Tech. Univ. 2020, 18, 4-15. [CrossRef]

56. Lel', Y.I.; Stenin, Y.V. Evaluation and planning of development of networks of motor transport communications at open pits. Izvestiya Vysshikh Uchebnykh Zavedenii Gornyi Zhurnal 2005, 3, 95-102. (In Russian)

57. Vasiliev, M.V. Principles of determining the moment of transition to a new type of transport in the development of deep quarries. Improvement of quarry transport: Works. IGDMCHM USSR 1970, 30, 14-17. (In Russian)

58. Kolga, A.; Moskovka, E. Environmental improving the utilization of dump trucks in the composition of supply truck train at open-pit mining. Modern Probl. Russ. Trans. Complex 2016, 6, 55-57. [CrossRef]

59. Galiyev, S.Z.; Boyandinova, A.A.; Adilkhanova, A.Z. Information and Methodical Base of Simulation Modeling of Excavator-Truck-Conveyor Complex Operation. In Proceedings of the Mine Planning and Equipment Selection (MPES 2010), Carlton, VIC, Australia, 1-3 December 2010; pp. 567-575.

60. Read, J.; Stacey, P. Guidelines for Open Pit Slope Design; CSIRO Pub: Collingwood, VIC, Australia, 2009; ISBN 978-041-587-441-0.

61. Paricheh, M.; Osanloo, M. How to Exit Conveyor from an Open-Pit Mine: A Theoretical Approach. In Proceedings of the 27th International Symposium on Mine Planning and Equipment Selection (MPES 2018); Widzyk-Capehart, E., Hekmat, A., Singhal, R., Eds.; Springer International Publishing: Berlin/Heidelberg, Germany, 2019; pp. 319-334. [CrossRef]

62. Bejari, H.; Daya, A.; Roudini, A. Selection of chromite processing plant site using fuzzy analytic hierarchy process (FAHP). J. Min. Environ. 2017, 8, 155-162. [CrossRef]

63. Xu, X.-C.; Gu, X.-W.I.; Wang, Q.; Liu, J.-P.; Wang, J. Ultimate pit optimization with ecological cost for open pit metal mines. Trans. Nonferr. Met. Soc. Chin. 2014, 24, 1531-1537. [CrossRef]

64. Wang, C.; Tu, S. Selection of an appropriate mechanized mining technical process for thin coal seam mining. Math. Probl. Eng. 2015, 2015, 10. [CrossRef]

65. Acaroglu, O.; Ergin, H.; Eskikaya, S. Analytical hierarchy process for selection of roadheaders. J. S. Afr. Inst. Min. Metall. 2006, $106,569-575$. 
66. Gupta, P.; Mehlawat, M.K.; Aggarwal, U.; Charles, V. An integrated AHP-DEA multi-objective optimization model for sustainable transportation in mining industry. Resour. Policy 2018. [CrossRef]

67. Patyk, M.; Bodziony, P.; Przylibski, T.A.; Kasza, D. Analysis of multiple criteria selection and application of APEKS method in haul truck mining transport process. E3S Web Conf. 2018, 71, 3. [CrossRef]

68. Bogdanovic, D.; Nikolic, D.; Ilic, I. Mining method selection by integrated AHP and PROMETHEE method. An. Acad. Bras. Cienc. 2012, 84, 219-233. [CrossRef] [PubMed]

69. Kasap, Y.; Subas1, E. Risk assessment of occupational groups working in open pit mining: Analytic Hierarchy Process. J. Sustain. Min. 2017, 16, 38-46. [CrossRef]

70. Golestanifar, M.; Aghajani Bazzazi, A. TISS: A decision framework for tailing impoundment site selection. Environ. Earth Sci. 2010, 61, 1505-1513. [CrossRef]

71. Vashlaev, I.I.; Selivanov, A.V. Determination of the horizontal equivalent of the movement of the rock mass of vehicles by the energy criterion when driving on slopes. Izvestiya Vysshikh Uchebnykh Zavedenii Gornyi Zhurnal 1997, 9-10, 78-80. (In Russian)

72. Bakhturin, Y.A.; Karmaev, G.D.; Bersenev, V.A. Issues of using cyclic-flow technology in open pit. Min. Inf. Anal. Bull. 2011, 3, 62-71. (In Russian)

73. Kuznetsov, D.V.; Kosolapov, A.I. Justification criteria for open pit mine depth and mining/haulage machinery parameters. IOP Conf. Ser. Earth Environ. Sci. 2019, 262, 12038. [CrossRef]

74. Komljenovic, D.; Kecojevic, V. Multi-attribute selection method for mining trucks. Soc. Min. Metall. Explor. 2006, 320, 94-104.

75. Guo, H.; Nguyen, H.; Vu, D.-A.; Bui, X.-N. Forecasting mining capital cost for open-pit mining projects based on artificial neural network approach. Resour. Policy 2019, 101474. [CrossRef]

76. Mohutsiwa, M.; Musingwini, M. Parametric estimation of capital costs for establishing a coal mine: South Africa case study. J. S. Afr. Inst. Min. Metall. 2015, 115, 789-797. [CrossRef]

77. Zhu, X.; Chen, Y.; Feng, C. Green total factor productivity of China's mining and quarrying industry: A global data envelopment analysis. Resour. Policy 2018, 57, 1-9. [CrossRef]

78. Peralta, S.; Sasmito, A.P.; Kumral, M. Reliability effect on energy consumption and greenhouse gas emissions of mining hauling fleet towards sustainable mining. J. Sustain. Min. 2016, 15, 85-94. [CrossRef]

79. Rodovalho, E.; Quaglio, O.; Felcsh, W.S., Jr.; Pascual, R.; de Tomi, G.; Tenório, J.A.S. Reducing GHG emissions through efficient tire consumption in open pit mines. J. Clean. Prod. 2020, 255, 120185. [CrossRef]

80. Northey, S.A.; Mudd, G.M.; Saarivuori, E.; Wessman-Jaaskelainen, H.; Haque, N. Water footprinting and mining. Where are the limitations and opportunities? J. Clean. Prod. 2016, 135, 1098-1116. [CrossRef]

81. Awuah-Offei, K. Energy efficiency in mining. A review with emphasis on the role of operators in loading and hauling operations. J. Clean. Prod. 2016, 117, 89-97. [CrossRef]

82. Rylnikova, M.V.; Strukov, K.I.; Olizarenko, V.V.; Turkin, I.S. Energy-efficient technologies in integrated mineral resources development: Prospects for application and estimate of parameters. Gornyi Zhurnal 2017, 11, 71-76. [CrossRef]

83. Le Gouill, C.; Poupeau, F. A framework to assess mining within social-ecological systems. Curr. Opin. Environ. Sustain. 2020, 44, 67-73. [CrossRef]

84. Joaquín Jara, J.; Pérez, P.; Villalobos, P. Good deposits are not enough. Mining labor productivity analysis in the copper industry in Chile and Peru 1992-2009. Resour. Policy 2010, 35, 247-256. [CrossRef]

85. Sitorus, F.; Cilliers, J.J.; Brito-Parada, P.R. Multi-criteria decision making for the choice problem in mining and mineral processing: Applications and trends. Exp. Syst. Appl. 2019, 121, 393-417. [CrossRef]

86. Kizil, M.S.; Abdalla, S.; Canbulat, I. Underground coal mine layout selection using analytical hierarchy process. Min. Technol. 2014, 123, 20-29. [CrossRef]

87. Saaty, T.L. The Analytic Hierarchy Process; McGraw Hill: New York, NY, USA, 1980; ISBN 978-007-054-371-3.

88. Chang, D.Y. Applications of the extent analysis method on fuzzy AHP. Eur. J. Oper. Res. 1996, 95, 649-655. [CrossRef] 